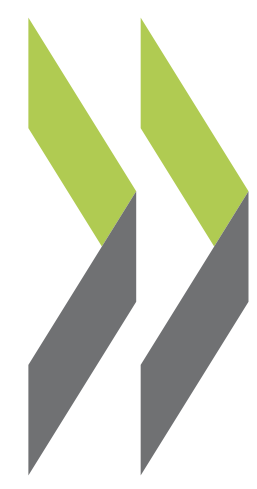

OECD Economics Department Working Papers No. 1642

Making Thailand's services sector more competitive through international trade

Kosuke Suzuki, Manasit Choomsai Na
Ayudhaya, Patrick Lenain 


\section{ECONOMICS DEPARTMENT}

\section{MAKING THAILAND'S SERVICES SECTOR MORE COMPETITIVE THROUGH INTERNATIONAL TRADE}

\section{ECONOMICS DEPARTMENT WORKING PAPERS No. 1642}

By Kosuke Suzuki, Manasit Choomsai Na Ayudhaya and Patrick Lenain

OECD Working Papers should not be reported as representing the official views of the OECD or of its member countries. The opinions expressed and arguments employed are those of the author(s).

Authorised for publication by Alvaro Pereira, Director, Country Studies Branch, Economics Department.

All Economics Department Working Papers are available at www.oecd.org/eco/workingpapers.

JT03469761 
OECD Working Papers should not be reported as representing the official views of the OECD or of its member countries. The opinions expressed and arguments employed are those of the author(s).

Working Papers describe preliminary results or research in progress by the author(s) and are published to stimulate discussion on a broad range of issues on which the OECD works.

Comments on Working Papers are welcomed, and may be sent to OECD Economics Department, 2 rue André Pascal, 75775 Paris Cedex 16, France, or by e-mail to eco.contact@oecd.org.

All Economics Department Working Papers are available at www.oecd.org/eco/workingpapers.

This document and any map included herein are without prejudice to the status of or sovereignty over any territory, to the delimitation of international frontiers and boundaries and to the name of any territory, city or area.

The statistical data for Israel are supplied by and under the responsibility of the relevant Israeli authorities. The use of such data by the OECD is without prejudice to the status of the Golan Heights, East Jerusalem and Israeli settlements in the West Bank under the terms of international law.

\section{(C) OECD (2020)}

You can copy, download or print OECD content for your own use, and you can include excerpts from OECD publications, databases and multimedia products in your own documents, presentations, blogs, websites and teaching materials, provided that suitable acknowledgment of OECD as source and copyright owner is given. Requests for commercial use and translation rights should be submitted to PubRights@oecd.org 


\section{Abstract/Résumé \\ Making Thailand's services sector more competitive through international trade}

Services are an important part of global economic activity and of international trade. Nevertheless, compared to its very large tourism sector, the sector of high-end business services in Thailand remains small. As IT and information, and professional services are traded indirectly through value chains and are now crucial elements of manufacturing, strengthening these services would benefit Thailand in its postCOVID-19 participation of global value chains, enhancing the competitiveness of its manufacturers. This paper analyses how Thailand can seize the opportunity of growing international trade in services. It points out that liberalising services sector markets would strengthen the competitiveness of the services sectors and boost productivity not only in the sectors, but also in manufacturing sectors that rely on these services as input. In this regard, Thailand can benefit more from service-oriented Preferential Trade Agreements (PTAs). Moreover, eliminating FDI restrictions would not only be crucial to spur employment and exports, but also benefit consumers. The paper identifies that, to maximise the benefits of services trade integration, Thailand needs to step up policies to re- and up-skill workers and make the labour market more flexible.

This Working Paper relates to the 2020 OECD Economic Assessment of Thailand (http://www.oecd.org/economy/thailand-economic-snapshot/).

JEL classification: F13, F14, F16, F17, F21, F63, F66, F68, L80

Keywords: Thailand, Trade in Services, Global Value Chains (GVCs)

\section{Renforcer la compétitivité du secteur des services thaïlandais grâce au commerce international}

Les services constituent une composante importante de l'activité économique mondiale et des échanges internationaux. Néanmoins, au regard de l'ampleur du secteur du tourisme, la dimension du secteur des services haut de gamme aux entreprises reste modeste en Thaïlande. Étant donné que les services informatiques et d'information et les services professionnels font l'objet d'échanges indirects via les chaînes de valeur et qu'ils constituent désormais des éléments cruciaux de la production manufacturière, leur renforcement serait bénéfique à la Thaïlande dans le cadre de sa participation aux chaînes de valeur mondiales après la pandémie de COVID-19, puisqu'il améliorerait la compétitivité de ses entreprises manufacturières. Nous étudions dans ce document la façon dont la Thaïlande peut exploiter les possibilités offertes par la croissance des échanges internationaux de services. Nous y soulignons que libéraliser les marchés de services permettrait de renforcer leur compétitivité et de stimuler la productivité, non seulement dans les secteurs de services eux-mêmes, mais aussi dans les secteurs manufacturiers qui les utilisent comme intrants. À cet égard, la Thaïlande pourrait tirer davantage parti d'accords commerciaux préférentiels axés sur les services. En outre, supprimer les restrictions à l'investissement direct étranger (IDE) contribuerait non seulement de manière cruciale à renforcer l'emploi et les exportations, mais profiterait également aux consommateurs. D'après nos travaux, pour maximiser les avantages de l'intégration commerciale dans le domaine des services, la Thaïlande doit aller plus loin en matière de recyclage professionnel et de renforcement des compétences de sa main-d'œuvre, et rendre son marché du travail plus flexible.

Ce document de travail est lié à l'Évaluation économique de l'OCDE de 2020 consacrée à la Thaïlande (http://www.oecd.org/fr/economie/thailande-en-un-coup-d-oeil/).

Classification JEL : F13, F14, F16, F17, F21, F63, F66, F68, L80

Mots clés : Thaïlande, échanges de services, chaînes de valeur mondiales (CVM) 


\section{Table of contents}

\section{Making Thailand's services sector more competitive through international trade}

Services are becoming more predominant in the Thai economy 6

Services also play an important role in international trade $\quad 9$

$\begin{array}{ll}\text { A stronger policy focus on services trade is promising } & 11\end{array}$

$\begin{array}{ll}\text { More mobility of foreign workers would spur business activity } & 18\end{array}$

Relaxing FDI rules would improve the quality of services $\quad 21$

Developing more service-oriented trade agreements would boost growth 23

Domestic suppliers need to leverage FDI to be more competitive 27

Innovation in business services could boost their direct exports 28

The tourism sector needs to overcome sustainability challenges $\quad 30$

Global connection can hone higher education's competitive edge 33

$\begin{array}{ll}\text { Annex A. Estimation of the services share } & 37\end{array}$

Annex B. Revealed comparative advantages $\quad 38$

RCA in terms of value added $\quad 38$

RCA in terms of GVC income 38

Annex C. Recovery of exports from the Global Financial Crisis $\quad 40$

Annex D. Estimation of productivity in GVCs $\quad 41$

Annex E. Effects of trade agreements on labour $\quad 42$

References $\quad 43$

\section{Tables}

$\begin{array}{lr}\text { Table 1. Services sectors in the GATS } & 20\end{array}$

$\begin{array}{ll}\text { Table 2. Macroeconomic impacts } & 25\end{array}$

Table 3. Recommendations to enhance Thailand's services trade integration 36

Table Annex A.1. A prolonged second wave of services growth 37

Table Annex C.1. Export recovery from the GFC - trade openness and export diversification 40

Table Annex E.1. Impacts of PTAs on different skill levels $\quad 42$

\section{Figures}

Figure 1. The share of services is increasing in GDP, while manufacturing's is declining 7

Figure 2. The services sector is the largest contributor to economic growth $\quad 7$

Figure 3. The share of the services sector is still lower in Thailand than in OECD countries 8

Figure 4. The share of services in GDP has risen 9

Figure 5. Although less vigorous, trade in services has increased gradually $\quad 10$

Figure 6. Services play an important role in global value chains $\quad 11$

Figure 7. Thailand's relatively high wages erode the competitiveness of its manufacturing sector 12

Figure 8. The recovery of services exports was strong after the last crisis $\quad 13$

$\begin{array}{lr}\text { Figure 9. Thailand's exports are more diverse } & 13\end{array}$ 
Figure 10. Thai services markets are more restricted than those in OECD countries 16

Figure 11. Restricted markets are likely to have a weak competitive edge 17

Figure 12. Thailand is competing for FDI with its regional peers $\quad 22$

Figure 13. Thailand's FDI restrictions are becoming relatively more stringent 23

Figure 14. Impacts on domestic production by sector 26

Figure 15. Impacts on exports and imports by sector 26

Figure 16. Thailand's trade facilitation performance has improved 27

Figure 17. Most of imported high-end services are embodied in intermediate goods 229

Figure 18. Thailand's high-end business services participate less in manufacturing GVCs 29

Figure 19. Some emerging countries have increased direct exports of high-end services 30

Figure 20. Thailand is one of the most popular tourist destinations 32

Figure 21. Thailand's tourism has an advantage in service infrastructure and natural resources 33

Figure 22. Foreign students become more important in higher education in many countries 34

Figure Annex B.1. Revealed comparative advantages of the Thai services and manufacturing sectors 39

Figure Annex D.1. Domestic GVC productivity by manufacturing sub-sectors 41

\section{Boxes}

Box 1. Is a higher services share associated with a higher income level? 9

Box 2. What is international trade in services? 15

Box 3. The OECD Services Trade Restrictiveness Index 18

Box 4. Policies of opening services markets to international trade 20

Box 5. How to improve the competitiveness of the logistics sector - OECD Competition Assessments in the Logistics Sector in Thailand $\quad 21$

Box 6. Impacts of an Asia-Pacific-wide trade agreement 25 


\title{
Making Thailand's services sector more competitive through international trade
}

\author{
By Kosuke Suzuki, Manasit Choomsai Na Ayudhaya and Patrick Lenain ${ }^{1}$
}

\section{Services are becoming more predominant in the Thai economy}

The importance of the services sector in Thailand has increased along with the rise of its income level. Economic development is associated with the expansion of the service economy. Thailand's economic growth has followed this typical pattern (Figure 1). As industrialisation took hold, the share of the agriculture sector in the economy decreased throughout the second half of the 20th century, while the share of the manufacturing sector in GDP increased. Since the late 1980s, post-industrialisation evolved in Thailand together with rapid income growth led by structural reforms and a foreign investment boom in the wake of the Plaza Accord. The services sector's share of value added and employment started to increase (Figure 1, Figure 2), while the share of the manufacturing sector flattened. After a slight decline in the mid2010s, the services sector's share in GDP increased again and it reached its highest level in 2018. This contrasts with the declining GDP share of the manufacturing sector, which peaked in 2010. Activity, measured by value added in the volume terms, has expanded more rapidly in services than in manufacturing, particularly after 2010 (Figure 2).

Reflecting the increase in the country's standards of living, the demand for services has also expanded. Households purchase more services, such as leisure, or outsource household chores as their incomes grow. In Thailand, the shares of "restaurants and hotels" and "recreation and culture" in household consumption expenditure increased from 19\% to $27 \%$ between 2000 and 2018 . Rapid urbanisation has enhanced this trend (Asian Development Bank, 2012[1]). The growing number of foreign tourists has also created strong demand for these services. In addition, firms in developed economies tend to purchase business services as intermediate input, such as financial services and information services, to satisfy their customers' needs and to improve their products. In Thailand, the share of "financial and insurance activities" in GDP increased from 4\% to 8\% between 2000 and 2018, which shows that, along with its

\footnotetext{
${ }^{1}$ Kosuke Suzuki and Patrick Lenain are members of the OECD Economics Department, and Manasit Choomsai Na Ayudhaya is member of the Office of the National Economic and Social Development Council, Thailand. The authors would like to thank Thai officials, members of the OECD Economic and Development Review Committee, Alvaro Pereira, Isabell Koske, Douglas Sutherland (from the OECD Economics Department) for useful comments and suggestions. The paper has also benefited from valuable contributions from Frank Van Tongeren, Christine Arriola, Inese Rozensteine, Sébastien Miroudot, Evdokia Moïsé, Silvia Sorescu, Frederic Gonzales (from the OECD Trade and Agriculture Directorate), Norihiko Yamano, Peter Horvát (from the OECD Directorate for Science, Technology and Innovation), Martin Wermelinger, Fernando Mistura, Wouter Meester, Ruben Maximiano (from the OECD Directorate for Financial and Enterprise Affairs), Tan Kay Kiang (from Economic Planning Unit, Prime Minister's Department, Malaysia), and Thanit Herabat (from the Office of the National Economic and Social Development Council, Thailand). Special thanks go to Isabelle Luong for statistical assistance, and Stephanie Henry for editorial coordination (from the OECD Economics Department).
} 
economic development, more sophisticated business services sectors have been growing fast. Nevertheless, despite its increasing presence, the services sectors' productivity shows a mixed picture. The productivity level of some services sectors, which embrace a high share of employment, such as the hospitality and restaurant industry (a quarter of the total employment) is lower than that of others, while high-productivity business services employ a smaller share of workers. Lifting the productivity level of the former sectors while stimulating job creation in the latter is therefore essential to improve overall productivity level, but this also calls for a new policy focus to foster the development of novel services sectors that can drive higher productivity growth in the long run in Thailand.

\section{Figure 1. The share of services is increasing in GDP, while manufacturing's is declining}

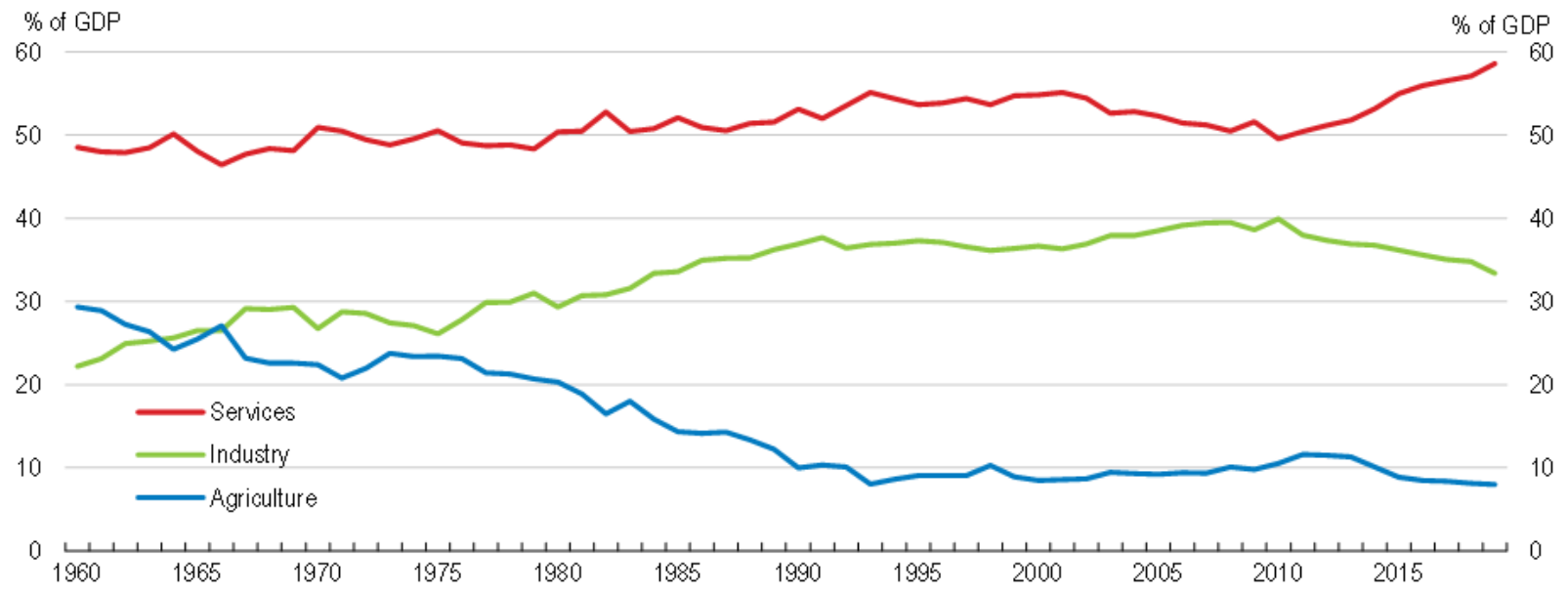

Note: Industry sector includes mining and quarrying, manufacturing, public utilities and construction.

Source: CEIC; National Statistical Office (NSO); National Economic and Social Development Council (NESDC).

Figure 2. The services sector is the largest contributor to economic growth
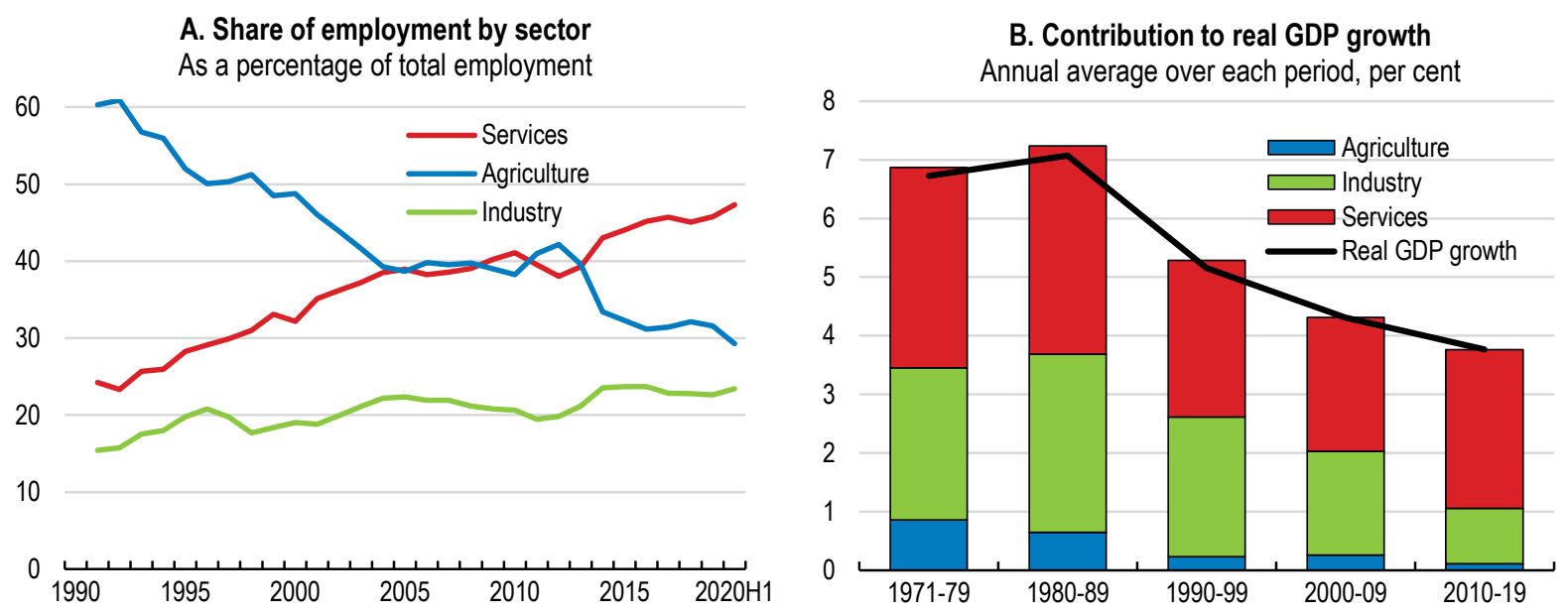

Note: Industry sector includes mining and quarrying, manufacturing, public utilities and construction.

Source: CEIC; Thai National Statistical Office (NSO); Asian Productivity Organisation, APO Database, February 2020; World Bank, World Development Indicators Database.

Despite its fast increase, the services sector is still smaller in Thailand than in most OECD countries (Figure 3). The services sector is therefore expected to continue expanding in the future. A simple 


\section{8 | ECO/WKP(2020)50}

assumption suggests that its share in GDP could reach approximately $70 \%$ (i.e. 10 percentage points higher than the current level) when GDP per capita reaches the OECD average. The expansion of the sector is likely to accelerate as Thailand approaches the high-income status, as previously happened in other countries (Asian Development Bank, 2012[1]]), (Park and Shin, 2012[2]), (Eichengreen and Gupta, $\left.2009_{[3]}\right)$. However, this may be a lower bound. New technologies - such as digitalisation, artificial intelligence, and blockchain - offer new opportunities for the services sector, and could make it an even more important driver of Thailand's economic growth than is currently expected (Box 1). In fact, the usage of digital technologies - from teleworking to telemedicine - has spiked globally due to a historic pandemic of COVID-19 starting from early 2020. While efforts to contain the virus continue around the world, this new development would accelerate even further and become enduring after the pandemic, including in Thailand.

Figure 3. The share of the services sector is still lower in Thailand than in OECD countries

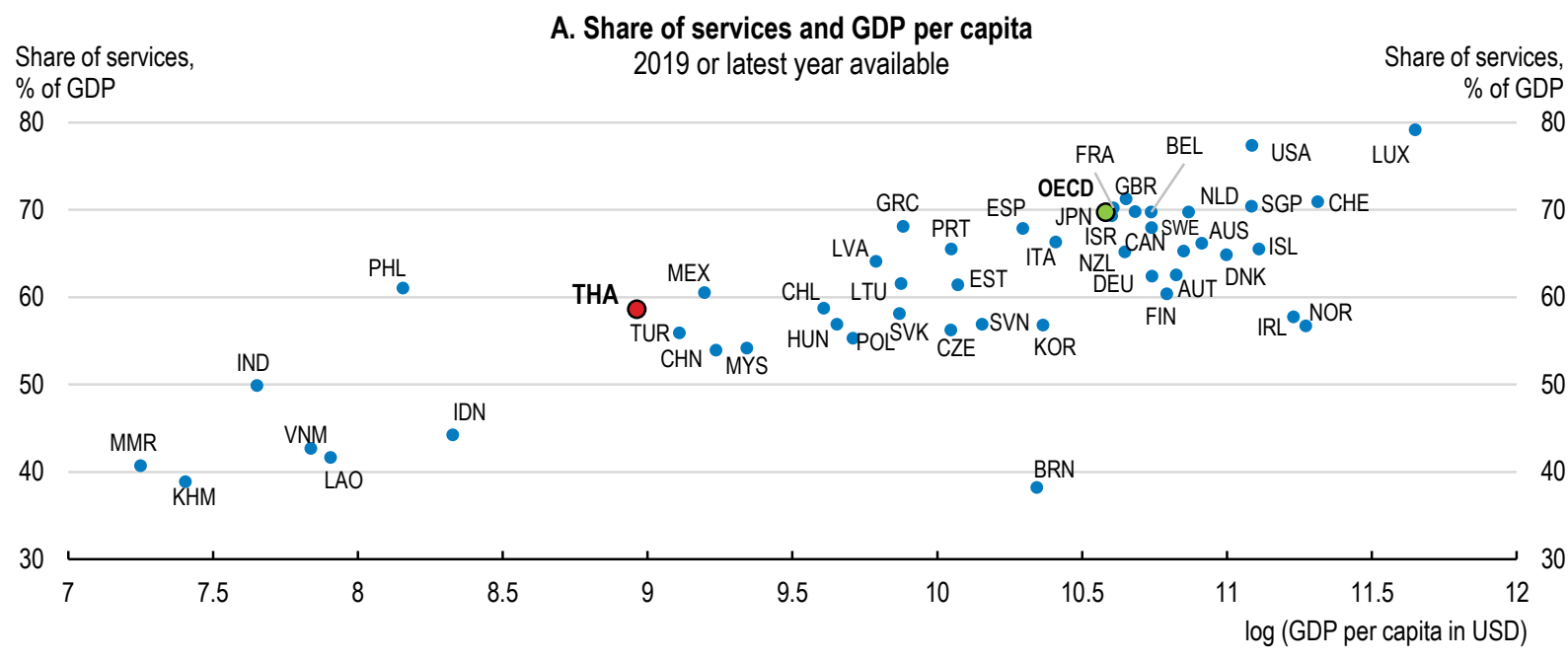

B. Size of the services sector

As a percentage of GDP, 2019 or latest year available

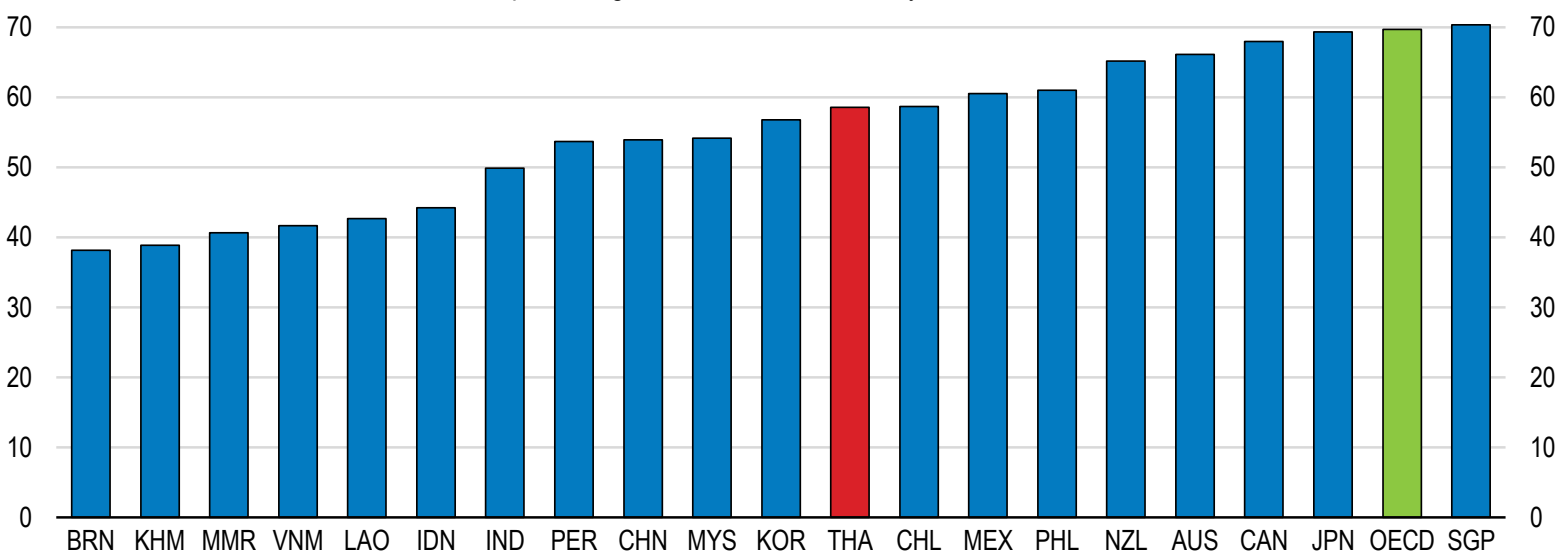

Source: World Bank, World Development Indicators Database. 


\section{Box 1. Is a higher services share associated with a higher income level?}

As the economy grows, modern business services, such as banking, insurance and information and communications, will become more important across the country, and complement existing traditional services produced and consumed locally, such as restaurants and hotels. Empirical work suggests that the economy experiences two waves of services sector growth as its income level rises, but the services share is expected to level off ultimately (Figure 4) (Park and Shin, 2012[2]), (Eichengreen and Gupta, $\left.2009_{[3]}\right)$. However, the recent rapid expansion of digitalisation might amplify this second wave and prolong its period (see Annex A). For example, the services share in GDP keeps growing in some advanced countries, where financial and information services, among other services, are thriving (Figure 4). Besides, the increased dependency of society on information technologies triggered by the COVID-19 pandemic would result in a permanent level shift in the services share through the change of people's behaviour.

\section{Figure 4. The share of services in GDP has risen}
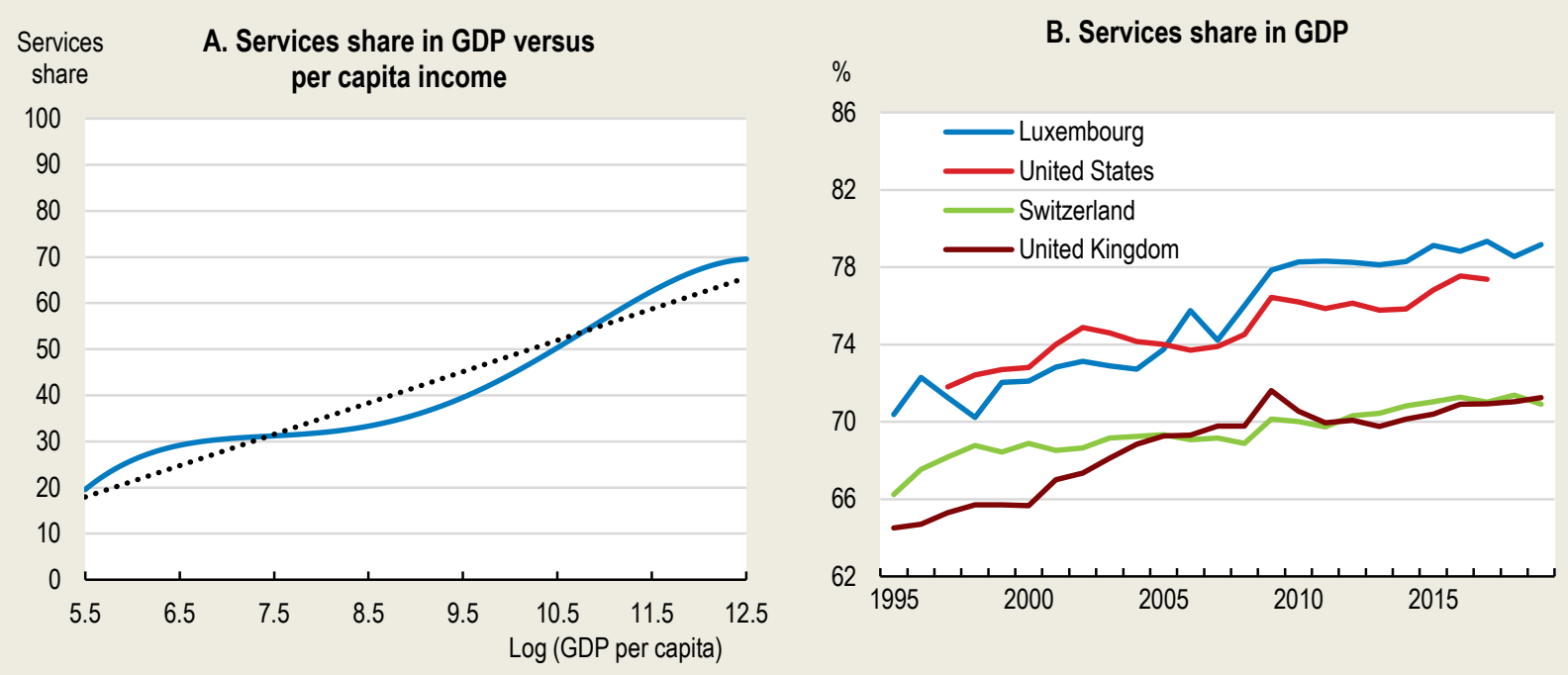

Note: Panel A shows a hypothetical case based on Eichengreen and Gupta (2009) and Park and Shin (2012).

Source: Eichengreen, B. and P. Gupta (2009), The Two Waves of Service Sector Growth; Park, D. and K. Shin (2012), The Service Sector in Asia: Is It an Engine of Growth?; World Bank, World Development Indicators Database.

\section{Services also play an important role in international trade}

Services, which are conventionally viewed as less tradable, are now frequently traded across national borders. Although less vigorously than trade in goods, Thailand's international trade in services has increased along with the expansion of its GDP, and its services trade share in GDP is now comparable to other regional peers and larger than in OECD countries (Figure 5). Particularly, inbound tourism constitutes a considerable part of Thailand's services exports, as the country is one of the most popular destinations. The number of tourists, particularly from China, grew rapidly recently, though it has plummeted since early 2020 due to the COVID-19 outbreak abroad.

The development of Global Value Chains (GVCs) accentuates the growing trade in services. As GVCs intensify trade in intermediate goods, they also increase cross-border transactions of associated intermediate services, such as logistics. The COVID-19 pandemic has revealed some vulnerabilities of GVCs, such as stretched value chains and lean stock management. However, the strengthening of GVCs 
would not reduce the importance of these associated services trade, but rather increase it, as value chains would need to become more diverse and redundant.

\section{Figure 5. Although less vigorous, trade in services has increased gradually}

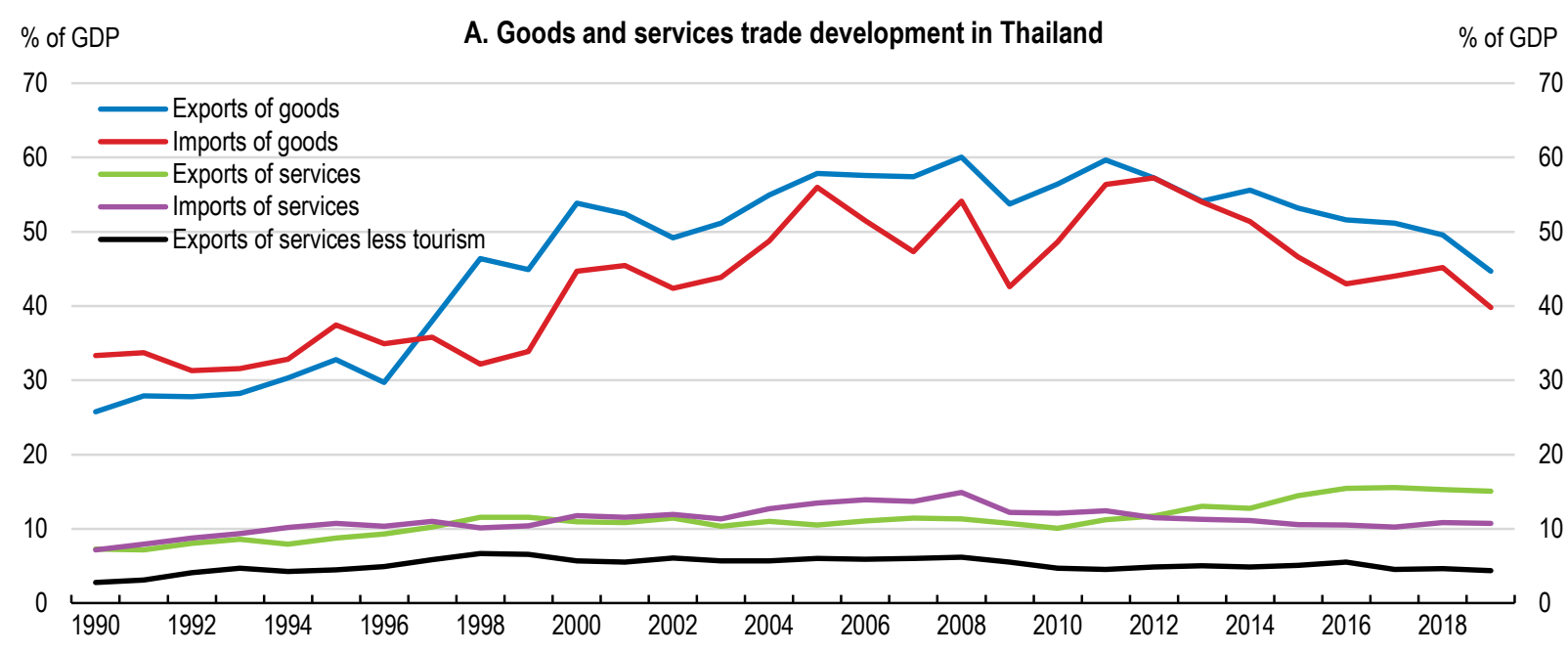

B. Imports of goods and services
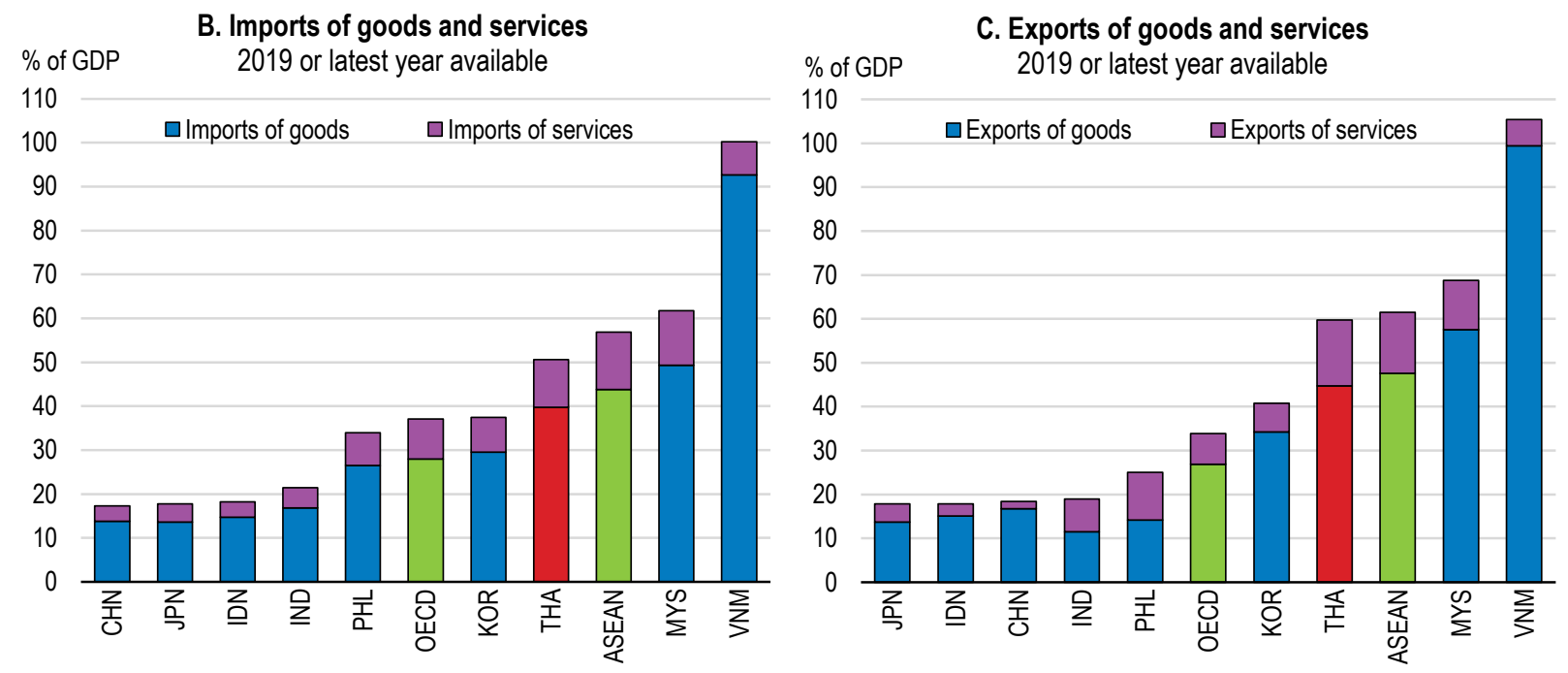

Source: World Bank, World Development Indicators Database; Thai National Statistical Office; CEIC.

Moreover, as modern manufacturing requires more services input, such as marketing, industrial design and information services, more services are embodied in intermediate and final goods. Although many goods that embody services are crossing borders in GVCs, these services are not captured in conventional trade statistics. According to the OECD Trade in Value Added Database, which can capture embodied products and services in trade, services have a much larger share than gross services exports if these embodied services are taken into account (Figure 6). The emerging pattern of services is more significant in value-added terms, which deduct imported services, than in gross terms that include imported services used to produce exporting products. 
Figure 6. Services play an important role in global value chains

As a percentage of gross exports, 2015

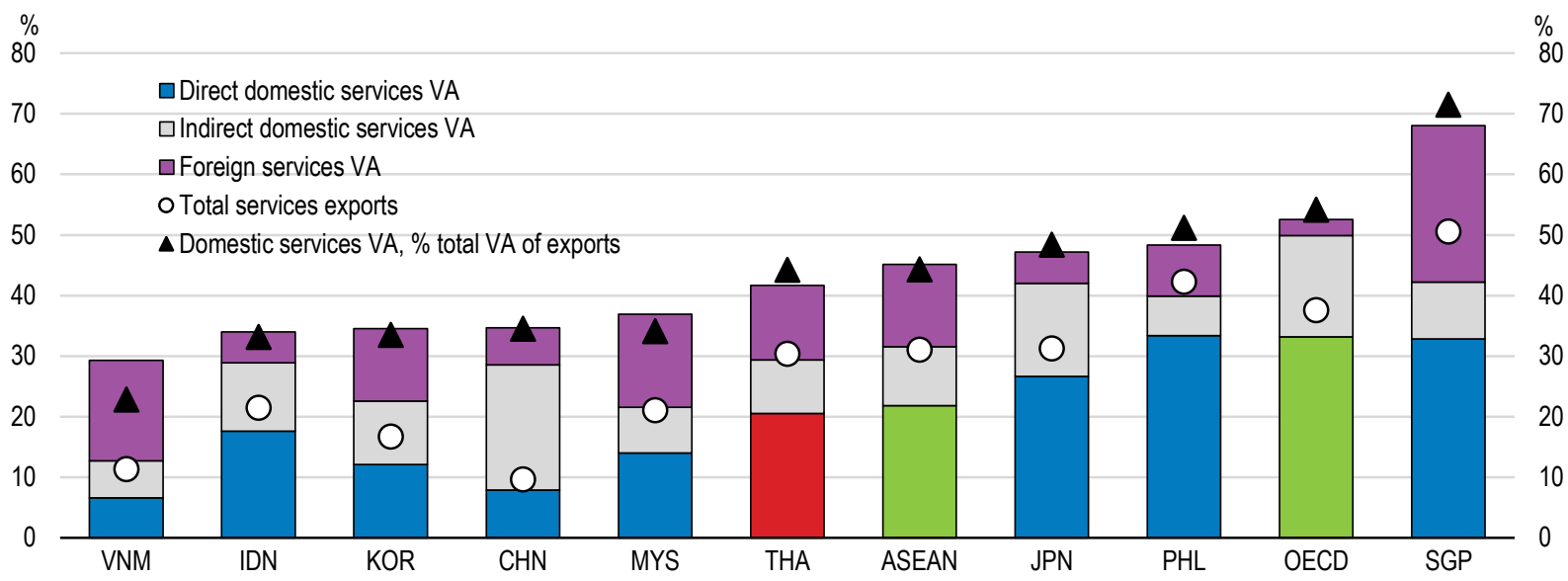

Source: OECD, Trade in Value Added (TiVA) Database.

\section{A stronger policy focus on services trade is promising}

The dynamism of Thailand's services sector needs to be boosted further. The manufacturing sector, which has actively participated in international trade, has been the main driver of growth of Thailand. However, this goods-exporting economic development model may have matured. As Thailand is becoming a highincome country, its cost competitiveness is getting eroded (Figure 7). Regional competition on product quality has become more significant because of technological progress made in neighbouring countries, such as China and Viet Nam. Manufacturing needs to further improve its products and production processes by using highly advanced technologies to compete in international markets. Besides, as modern manufacturing products are associated with unbundled services contents that are provided separately, such as maintenance and customer services, more trade in goods goes hand in hand with more trade in services. This will provide Thai firms tremendous business opportunities. 
Figure 7. Thailand's relatively high wages erode the competitiveness of its manufacturing sector Annual wages in manufacturing by occupation, current USD thousand
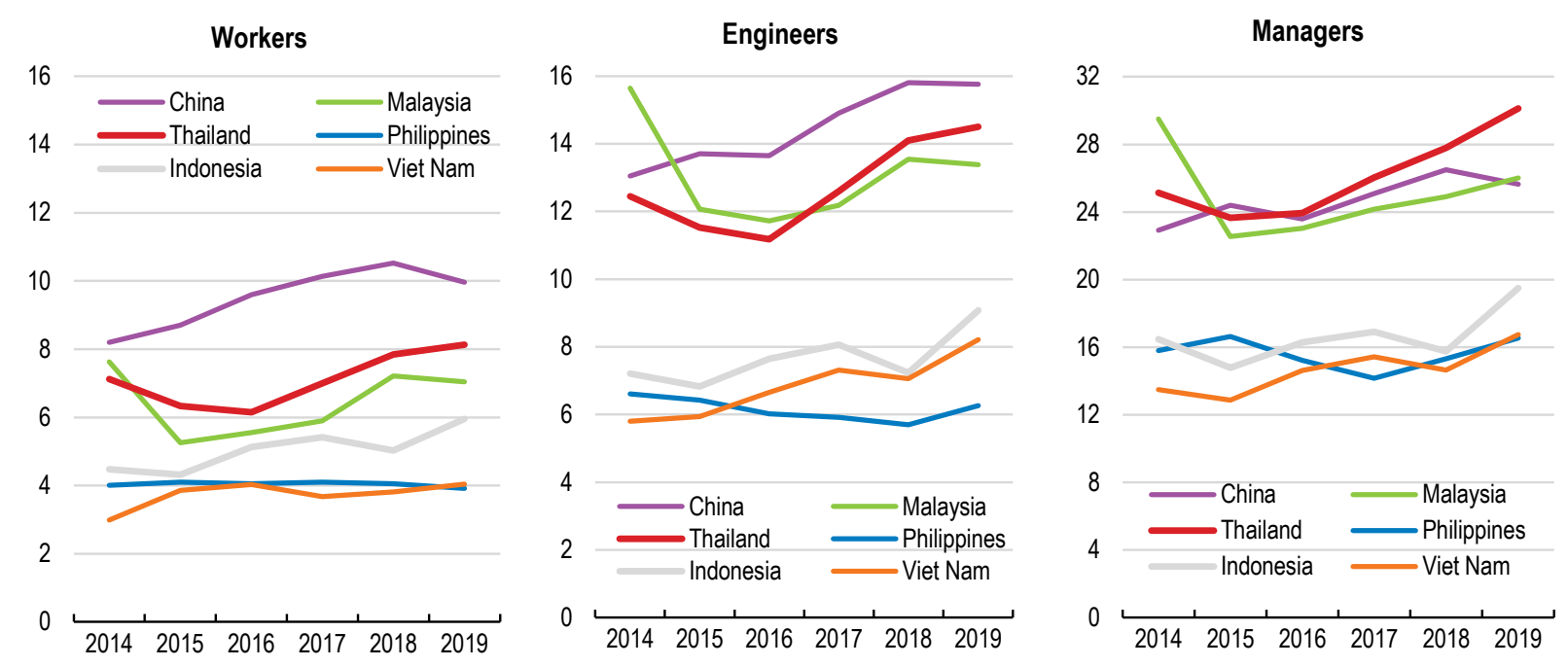

Source: JETRO (2019), Survey on Business Conditions of Japanese Companies in Asia and Oceania.

Moreover, as advanced manufacturers conduct core services businesses required in upstream and downstream production processes, such as information and distribution services, by themselves, the nature of manufacturing is changing. These developments call for policies shedding more light on the service economy. Nevertheless, the rise of services does not itself guarantee economic prosperity in the future. The productivity levels of some services sectors are lower than that of manufacturing in Thailand (Noland, Park and Estrada, 2012[4]). In addition, the competitive edge of some high-end business services - namely, IT and information, and other business services, the latter of which includes professional services - is rather weak in Thailand, which needs to be enhanced (see Annex B).

Strengthening export-oriented services sectors would also help economic growth of Thailand be more resilient. During the past crises, Thailand's services trade was more stable but less vigorous than its merchandise trade. Nevertheless, inbound tourism, where Thailand has a competitive edge, contributed a lot to a strong economic recovery from the 2011 floods (Figure 8). Nurturing newly evolving services sectors would help expand Thailand's export markets, and thus would make its exports more robust (see Annex C). Given the accelerating digitalisation, strengthening the export competitiveness of high-end business services sectors would be crucial. In addition to its strong commitment to international trade, thanks to a wide range of exports products from agriculture to manufacturing goods, Thailand's exports consist of an extensive coverage of products and are more distributed compared with regional peers (Figure 9). Developing new and competitive services exports would further strengthen its export diversification. 
Figure 8. The recovery of services exports was strong after the last crisis
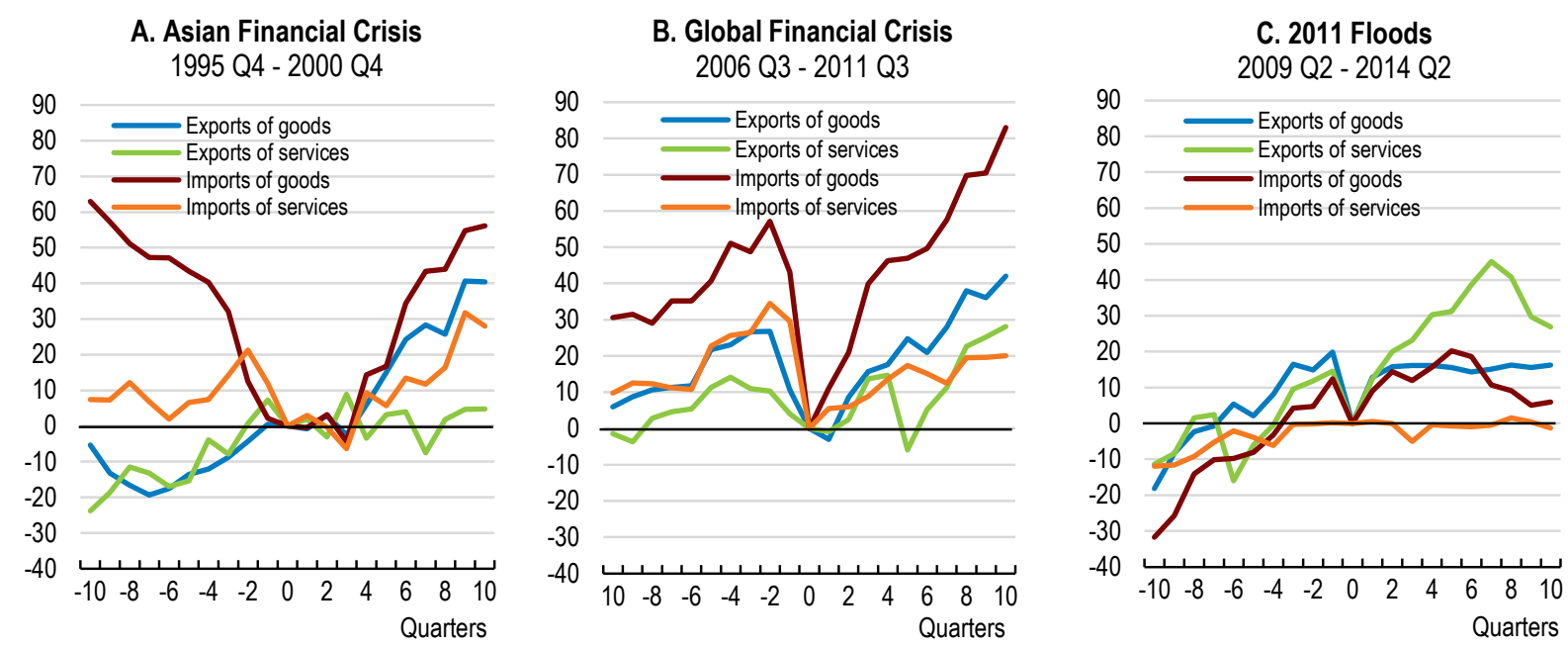

Note: The curves show the percentage change of the trade indicators relative to the trough (quarter 0 ) of each period crisis. Quarter 0 corresponds to 1998 Q2 for the Asian Financial Crisis, 2009 Q1 for the Global Financial Crisis, and 2011 Q4 for the 2011 Floods.

Source: NESDC.

Figure 9. Thailand's exports are more diverse
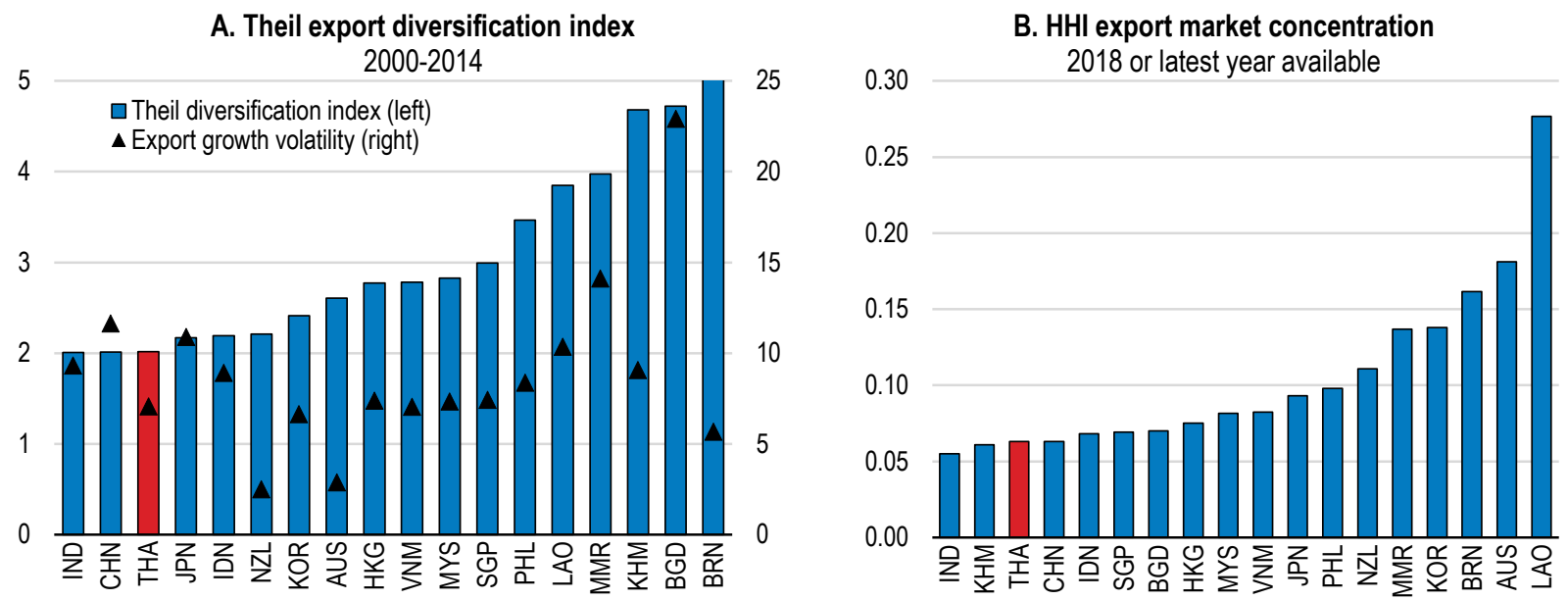

Note: The Theil index measures the extent of diversification across a country's exports on products and partners. A country with exports that are more distributed or contain a wider range of products and partners has a smaller value.

The Hirschman Herfindahl index $(\mathrm{HHI})$ is a measure of the dispersion of trade value across an exporter's partners. A country with trade (exports or imports) that is concentrated in a very few markets will have an index value close to 1 . Similarly, a country with a perfectly diversified trade portfolio will have an index close to zero.

Source: IMF; World Bank, World Integrated Trade Solution Database.

\section{Promoting services trade calls for holistic reforms in services markets}

As more services are crossing borders, Thailand could consider more services market reforms in the context of globalisation. However, policy for trade in services should focus not only on cross-border trade but also on the functioning of domestic markets, since services are provided through a range of modes, such as foreign affiliates or foreign workers in Thailand (Box 2). For example, foreign affiliates can act as suppliers of more sophisticated services to the Thai manufacturing and consumers, expanding the services 
sectors in Thailand thus also benefiting Thailand's domestic economy. Estimates suggest that the services provided in Thailand are important contributors to productivity of manufacturing (see Annex D). Ameliorating services quality needs the overall reforms in services markets. Particularly, the following four areas are most relevant to Thailand.

- Opening the services markets more to foreign firms and workers;

- Developing more service-oriented Preferential Trade Agreements (PTAs);

- Nurturing high-end business services, such as information and professional services;

- Improving the quality of consumer services, such as tourism and higher education.

Reforming the services sector would also benefit the Thai consumers. Throughout the last two decades, the share of services in total household consumption has declined despite their increasing volume. As consumer services, such as retail trade and leisure, are more geared to domestic demand, particularly towards household consumption, this would also help rebalance economic growth to a more stable and durable path amid the looming ageing society. In an ageing society, elderly people may purchase different types of services compared to younger people: in addition to health-related services, demand for leisure with high value-added would increase. If elderly people decide to participate in the labour market more actively, education services might be more consumed than now for re- and up-skilling.

Due to the global pandemic of COVID-19, a number of countries including Thailand have imposed border restrictions to ban the entry of foreign visitors. However, as a wide range of services trades is associated with the cross-border mobility of people (e.g. experts are dispatched to a host country to set up a new factory or to renew equipment), it would be also essential to keep the country open to abroad, while containing the resurgence of virus infections. 


\section{Box 2. What is international trade in services?}

As most services are intangible and cannot be stored, the notion of international trade in services is quite different from that of goods, the latter of which is discernible when goods cross the national borders. The scale and scope of trade in services are much broader than those of goods. The World Trade Organisation (WTO) distinguishes four different types of trade in services.

- Mode 1: Cross-border trade of services - this is similar to trade in goods. An example is information and audio-visual services provided by foreign firms via the Internet;

- Mode 2: Consumption abroad - consumers purchase services visiting other country. This includes tourism, education and healthcare services;

- Mode 3: Service provision by commercial presence abroad - Firms establish affiliates in other country to provide their services directly to foreign customers. Foreign investment is a snapshot of this activity, as foreign investment, if it is not merger and acquisition, aims at setting up commercial presence abroad;

- Mode 4: Service provision by foreign workers - foreign workers provide services visiting or living in other country as an independent supplier or employee. Professional services, such as engineering and consultancy, are included in this category.

The traditional trade statistics, i.e. the Balance of Payment, can only capture trade in Mode 1 and a fraction of Mode 2 (tourism) and 4 (part of commercial services). Besides, there are two other types of trade in services, which the traditional trade statistics cannot capture appropriately. The OECD Trade in Value Added Database is a tool to analyse embodied services trade.

- Embodied services: Services are indirectly traded as embodied contents of goods, such as marketing and industrial design. GVCs amplify the volume of embodied services trade;

- Within-firm transaction: Multinational firms trade services internally, such as management.

\section{Opening up services markets would improve Thailand's competitiveness}

The OECD Services Trade Restrictiveness Index (STRI), which is newly available for Thailand, provides a landscape of regulatory openness in 22 business services sectors (Box 3 ). The index suggests that, overall, Thailand is less open to the delivery of foreign services compared with OECD countries, China and Malaysia, while less restrictive than Indonesia and India (Figure 10). Rail freight transport, accounting services and insurance services are the three sectors with the highest score relative to the averages of other countries (OECD, 2020[5]). Besides, the restricted sectors in Thailand are likely to be less competitive in international trade (Figure 11). A further opening of the markets would not only boost productivity and improve export performance through enhanced resource allocation, but also provide the long-run dynamic gains by facilitating knowledge transfer and innovation, which are more crucial for Thailand's economic achievement (Box 4). Competition and regulatory reforms would also invigorate domestic services sectors. The OECD's Competition Assessment Toolkit (CAT) identifies potential competition barriers in the Thai logistics sector (OECD, 2020[6]) (Box 5). 
Figure 10. Thai services markets are more restricted than those in OECD countries Index score from 0 (open) to 1 (closed)

A. Overall STRI

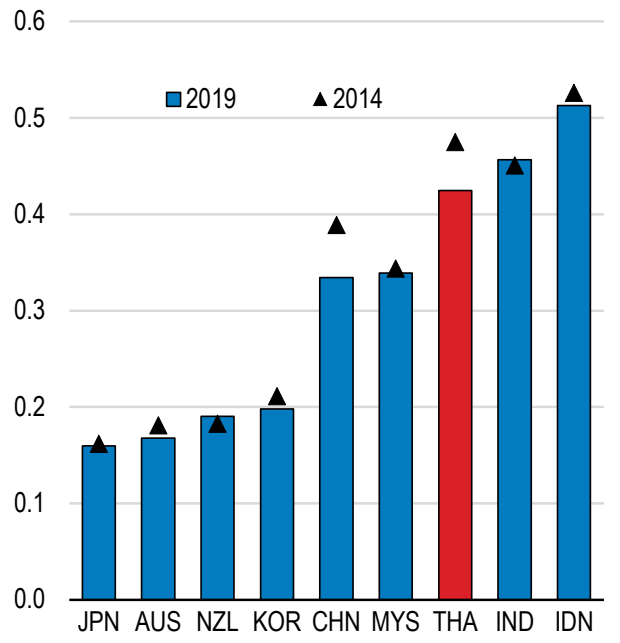

B. STRI composition, 2019

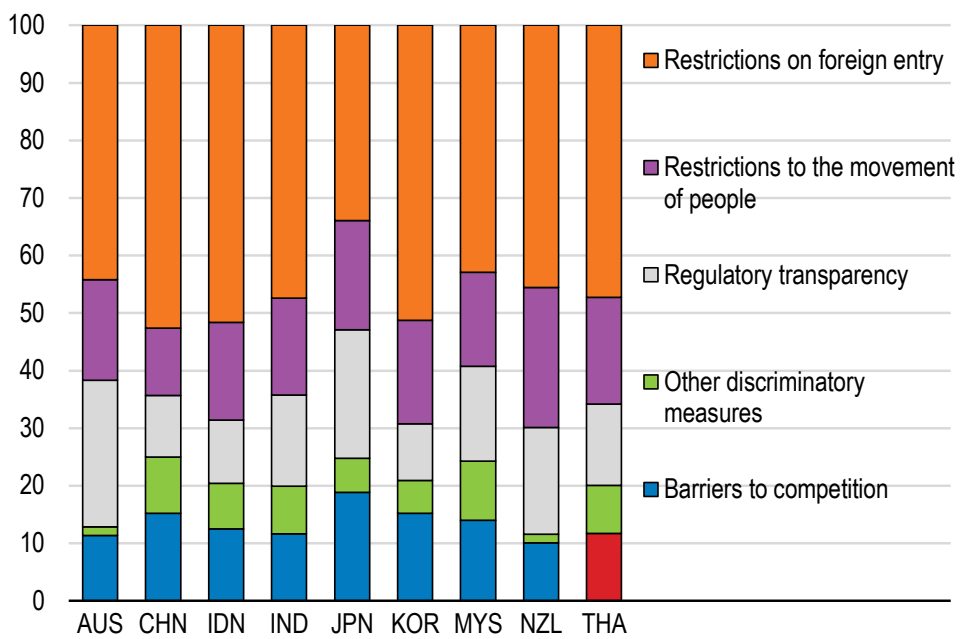

C. STRI by sector, 2019

$\square$ Restrictions to the movement of people $\quad \square$ Regulatory transparency

$\square$ Barriers to competition $\square$ Other discriminatory measure o Minimum

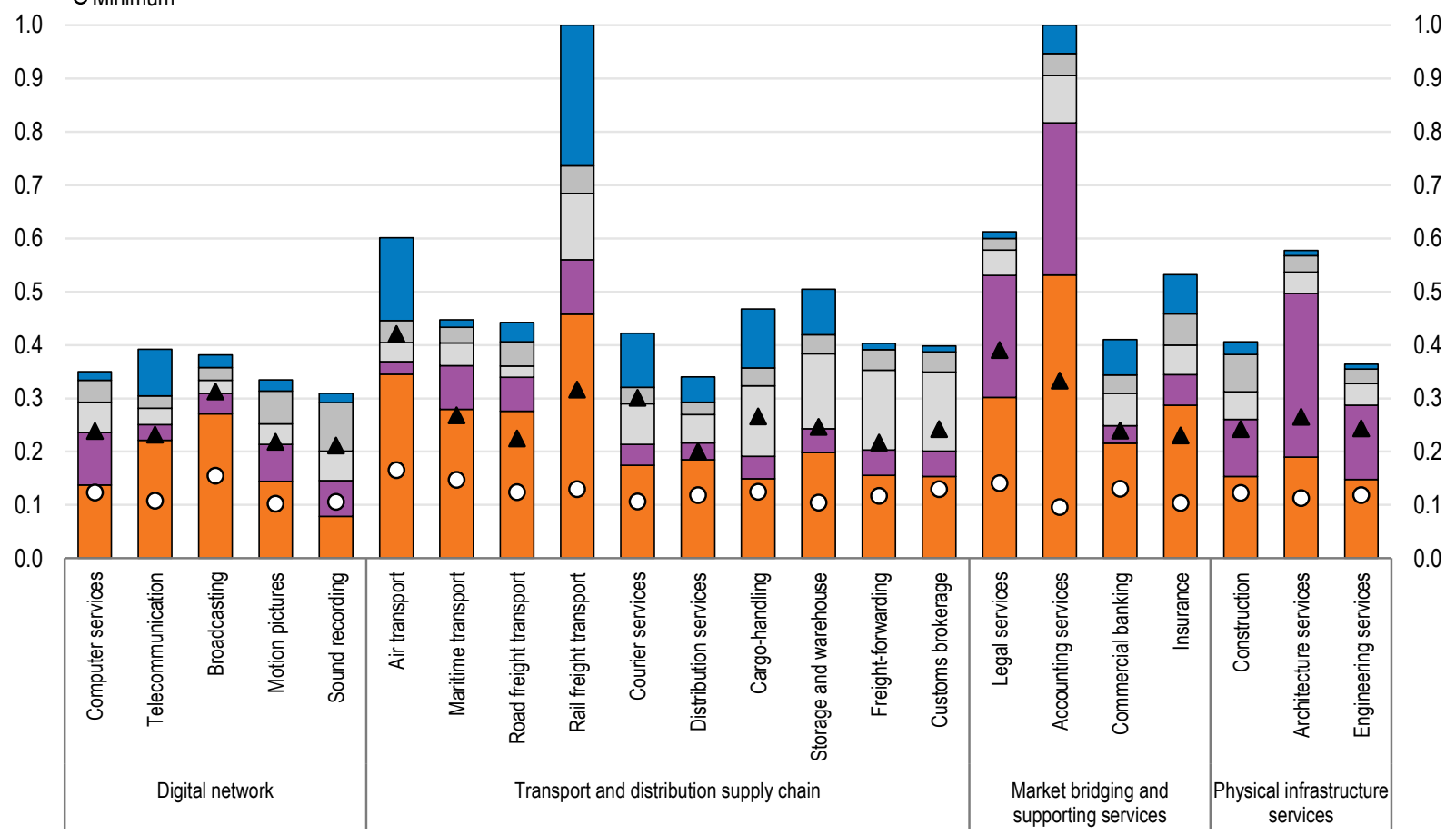

Source: OECD, Services Trade Restrictiveness Index Regulatory Database. 
Figure 11. Restricted markets are likely to have a weak competitive edge

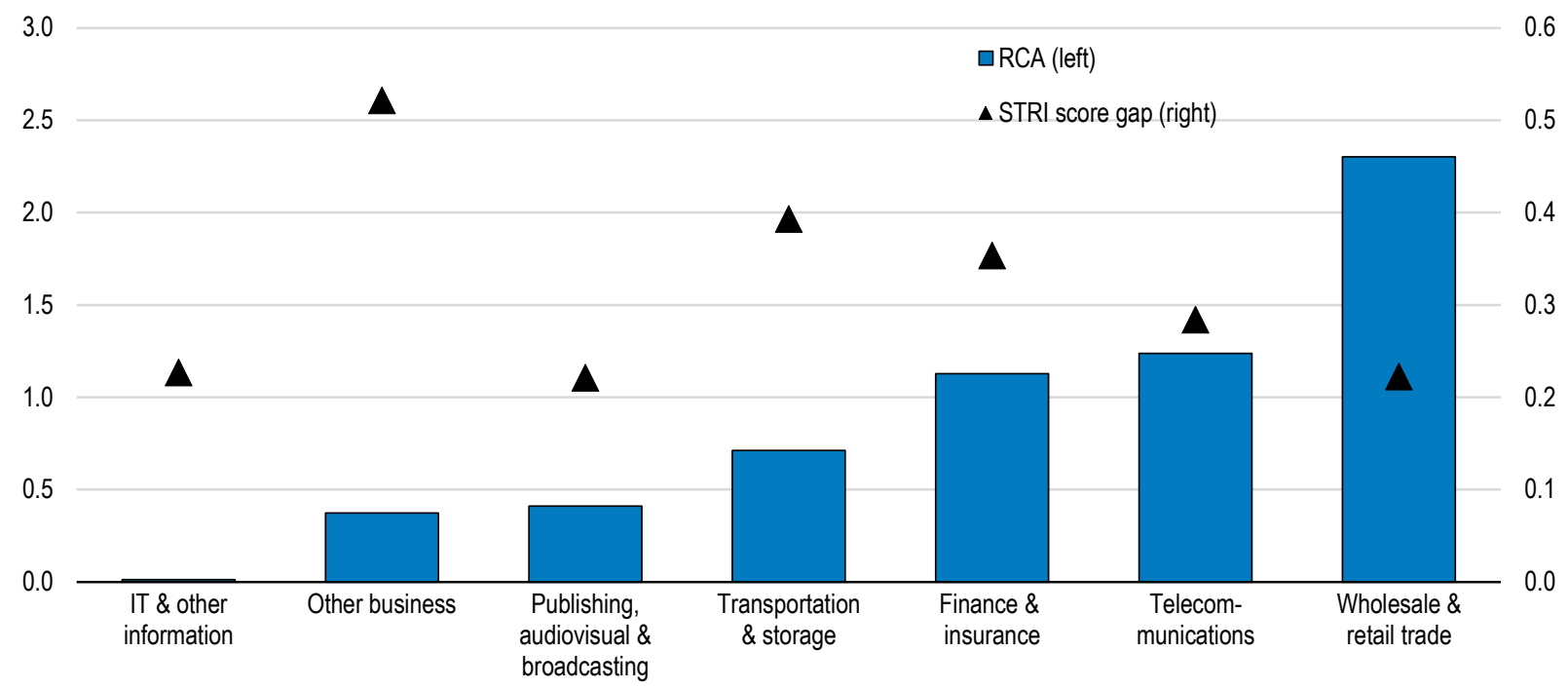

Note: RCA is the revealed comparative advantage in terms of value added (for more detailed information, see Annex B). An industry with an RCA $>1$ has a comparative advantage. STRI score gap is the difference between the minimum score and the score of the sector (calculated by simple average of the corresponding sub-sectors).

Source: OECD, Trade in Value Added (TiVA) Database and Services Trade Restrictiveness Index (STRI) Regulatory Database. 


\section{Box 3. The OECD Services Trade Restrictiveness Index}

The OECD Services Trade Restrictiveness Index (STRI) is a regulatory database containing policy information on 22 major services sectors for the 36 OECD member countries, key partners (Brazil, China, India, Indonesia and South Africa) and Colombia, Costa Rica, Russia. In 2019, Thailand was added to the STRI covering laws and regulations in force since 2014.

STRI is composed of two distinct but complementary instruments: a services trade regulatory database, which collects information on applied services trade policy, and a services trade restrictiveness index measuring the trade restrictiveness of such policies. These instruments provide a rich source of information for trade policy analysts, trade negotiators and researchers, and a tool for the impact assessment of trade liberalisation as well as unilateral services sector reform. It can also help governments identify best practice and focus their domestic reform efforts on priority sectors and measures. It helps trade negotiators to identify restrictions that impede trade and is a source of regulatory transparency for business seeking to enter foreign markets.

The database records not only limitations on market access and national treatment of foreign services suppliers, but also behind the border regulations that de facto impede the establishment and operation of foreign services suppliers. However, STRI does not take into account preferential trade agreements.

Launched in 2014, STRI is updated annually, offering a comprehensive and transparent overview of global trends in services trade regulations, while facilitating deeper analysis of the effects that such regulations have on trade in services and the wider economy. The yearly update incorporates changes that have been introduced through new or amended laws and regulations.

Note: This note is prepared by Trade and Agriculture Directorate, OECD.

\section{More mobility of foreign workers would spur business activity}

Facilitating the cross-border movement of skilled workers is an important element in services trade. Foreign investment entails expert visits, and professional services are often provided with close proximity. As these services tend to be more skill-intensive, this is particularly relevant to Thailand, given the shortages of skilled labour.

Thailand has a range of restrictions on the movement of foreign workers. A company is entitled to hire up to ten foreign workers at a ratio of THB 3 million in capital per foreign worker. The rule of $4: 1$ ratio of local and foreign employees on a full-time basis is applied, although exemptions exist, subject to approval by the Board of Investment (BOI) and joint ventures with major Thai shareholders. Thailand also applies labour market tests and the duration of stay is limited to 12 months: the ability to compete and the opportunity to work for Thai nationals need to be considered prior to issuance of work permit for foreigners. Besides, foreigners have to notify their current addresses every 90 days. Given the importance of the issue, the BOI can expedite immigration process of skilled foreign workers. With the Smart Visa procedure, foreign skilled workers earning more than THB 200000 per month are exempted from some restrictions, including a four-year stay instead of a general one-year stay. As the Smart Visa only covers the targeted industries, this could be expanded further to other fields.

In March 2019, the Thai Immigration Bureau announced the enforcement of the "Notification of Residence of Foreigners" (TM30) rule under the longstanding Immigration Act, B.E. 2522 (1979) due to security reasons. This requires property owners to report all foreigners who stay overnight on their premises within 
24 hours. Foreigners who fail to provide an official receipt for TM30 compliance will not be eligible to apply for visa extensions. The government has been reviewing the rule under the on-going regulatory reform, and the restrictions have been partially relaxed. From June 2020, if the foreigner returns to the same premises after a temporary leave, the property owners no longer need to file the report once again with an immigration office. Nevertheless, as the extra reporting of TM30 constitutes an additional burden for foreign firms to extend their businesses in Thailand, this could be further streamlined.

Moreover, ASEAN has developed Mutual Recognition Arrangements (MRAs) for skilled labour mobility within the region since 2005, which now cover seven different professional occupations. So far, the number of registered professionals is limited; in case of engineers, only 3735 were registered as of 2019, of which 220 from Thailand, probably due to differences in languages and strong family ties in Asian countries. Nevertheless, Thailand could attract engineers from other ASEAN countries because of a wage premium for engineers (Asian Development Bank, 2019 ${ }_{[7]}$ ). Adding more professions, particularly other high skilled vocational occupations, to these agreements would be useful (Asian Development Bank, 2019[7]). 


\section{Box 4. Policies of opening services markets to international trade}

\section{Framework of services trade liberalisation under the GATS}

As trade in services occurs through the broader channels of transactions (see Box 2), policy measures affecting trade in services are also broader than those for goods. WTO members agreed on the General Agreement on Trade in Services (GATS) to advance services trade liberalisation progressively. It covers 12 different business and consumer services.

\section{Table 1. Services sectors in the GATS}

\begin{tabular}{l|l}
\hline \multicolumn{2}{c}{ Services Sectoral Classification List } \\
\hline Business services (including professional services and computer services) & Financial services (including insurance and banking) \\
\hline Communication services & Health-related and social services \\
\hline Construction and related engineering services & Tourism and travel-related services \\
\hline Distribution services & Recreational, cultural and sporting services \\
\hline Educational services & Transport services \\
\hline Environmental services & Other services not included elsewhere \\
\hline
\end{tabular}

Source: World Trade Organisation.

Two aspects of policy measures are relevant to services trade liberalisation, namely:

- Market Access: This is whether or not a country imposes restrictions on service activities (i.e. limitations on the number of suppliers, volume of transaction, assets, output or employees), the type of legal entity or joint venture and participation of foreign capital;

- National Treatment: This is whether or not a country gives non-discriminatory treatments to foreign services and foreign suppliers compared to domestic ones, such as tax exemptions and residency requirements.

Under the GATS, WTO members have announced the extent of market openness with regard to the three dimensions, which is called the country's "schedule of commitments":

1. 12 sectors (which embrace some 160 sub-sectors);

2. Market Access and National Treatment;

3. Four modes of supply (see Box 2).

The OECD Services Trade Restrictiveness Index (STRI) evaluates the degrees of market liberalisation focusing on Mode 1, 3 and 4 together with general regulatory frameworks and barriers to competition, such as favourable treatments of state-owned enterprises.

\section{Preferential Trade Agreements as a driving force of services trade liberalisation}

Preferential Trade Agreements (PTAs), which cover services, often use the same framework as the GATS. The thrust of PTA participation is whether or not participants liberalise services markets beyond the commitments made under the GATS ("WTO plus"). In case a country imposes similar restrictions on domestic service suppliers, such as the restriction on opening new merchandise stores, trade liberalisation entails domestic market reforms, which would bring benefits to domestic consumers. 


\section{Box 5. How to improve the competitiveness of the logistics sector - OECD Competition Assessments in the Logistics Sector in Thailand}

The logistics market in Thailand has been growing rapidly following a significant investment in infrastructure over the last few years, so ensuring competition in the logistics services sector is important to reap the benefits of those investments.

The OECD has undertaken two competition projects in the logistics services sector in Thailand by year end 2019 - one on the assessment of rules and regulations and another of the analysis of competitive neutrality and the role and competition impacts of state-owned enterprises (SOEs) in the small package delivery services - crucial for the flow of e-commerce.

The competition assessment project focused on five subsectors of the logistics market (freight transportation (excluding air), freight forwarding, warehousing, small package delivery services and value-added services). Working in close co-operation with the Office of Trade Competition Commission (OTCC) and other public stakeholders in Thailand, the OECD scrutinised more than 100 pieces of sector-relevant legislation in Thailand and issued more than 60 recommendations. Some recommendations are:

- Publish a consolidated, updated version of every law relevant to logistics, including subsequent amendments;

- Introduce digitalisation for all application procedures for logistics-related authorisations and allow online applications;

- Remove the provision requiring a multimodal transport operator (MTO) to hold an authorisation for each branch it operates;

- Regularly assess market demand and consider re-negotiating with co-signatories the maximum number of licences for cross-border freight transport by road;

- Adopt an implementing act (e.g. ministerial regulations or OTCC guidelines) to clarify (a) that SOEs are clearly covered by the Trade Competition Act, and (b) the scope of the "public interest" exemption under Section 4(2) of the 2017 Trade Competition Act.

If fully implemented, these recommendations can be expected to generate significant benefits to the Thai economy, and more broadly to ASEAN. The full implementation of the recommendations set out in this report is expected to deliver positive long-term effects on employment, productivity, growth and positively affect the ability of businesses to compete.

Note: This note is prepared by Directorate for Financial and Enterprise Affairs, OECD.

Source: (OECD, 2020[6]), (OECD, 2020[8]).

\section{Relaxing FDI rules would improve the quality of services}

While the manufacturing sector has a dominant share in inward FDI, the services sector also has a significant share, particularly the financial sector (mostly in the form of mergers and acquisitions), the real estate sector, and the wholesale and retail trade sectors (Figure 12). Nevertheless, with Cambodia, Laos, Myanmar and Viet Nam (the CLMV countries) having considerably increased their inward FDI flows over the past decade, Thailand needs to restore its attractiveness as an FDI destination, particularly in services sectors. 
Figure 12. Thailand is competing for FDI with its regional peers

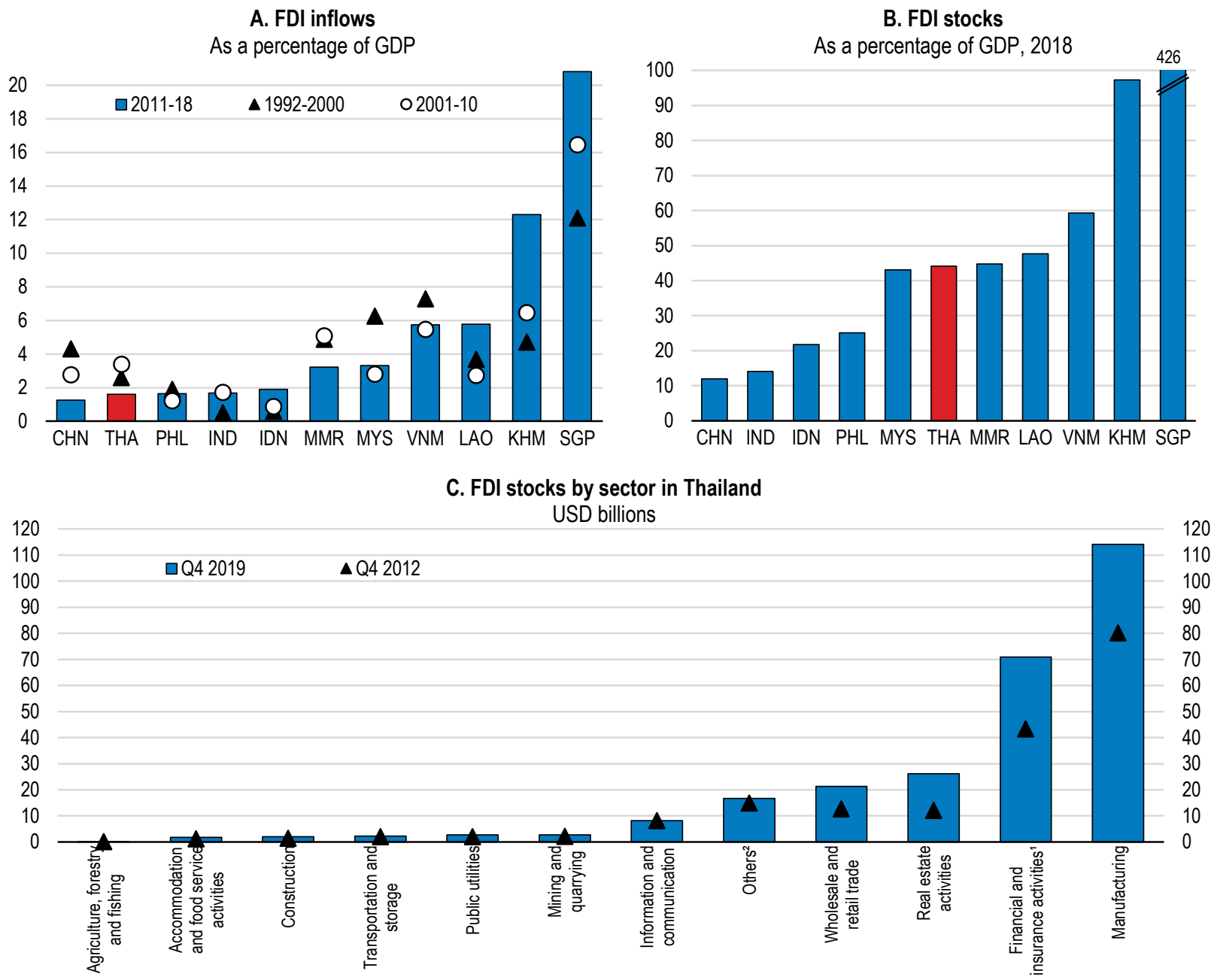

1. Includes investments in investment companies.

2. Includes transactions in debt securities, and trade credits between affiliated enterprises.

Source: UNCTAD; Bank of Thailand.

The OECD FDI Restrictiveness Index suggests that, despite past policy efforts, Thailand's FDI restrictions are no longer the lowest in the region as they used to be, because regional peers have opened their markets drastically (Figure 13). Moreover, Thailand tends to be stricter in services sectors. Thailand imposes minimum capital requirements on foreign investment (THB 2 million in general), which is quite high compare with other emerging economies. The Foreign Business Act B.E.2542 (1999) is the main law governing FDI and defining foreign ownership, which is a $50 \%$ or more foreign shareholding. The law restricts foreign access to certain businesses for security reasons (List 2: such as domestic transport including railways) and the promotion of domestic firms (List 3: 21 sectors, mostly services). The BOI has the power to grant permission of full foreign ownership of firms in these sectors, as long as other laws do not state restrictions. Nevertheless, these rules generate uncertainty and risk rent-seeking behaviour by incumbents. Reviewing these rules, in view of lower thresholds and a negative list, actually narrowing down the list of sectors and activities in which foreign investors are treated in a discriminatory manner, would likely spur foreign investment in services sectors (OECD, 2020[9]). 
Figure 13. Thailand's FDI restrictions are becoming relatively more stringent

OECD FDI Regulatory Restrictiveness Index, scaled from 0 (open) to 1 (closed)

A. The Thai FDI regulatory restrictiveness index hasn't changed much over time

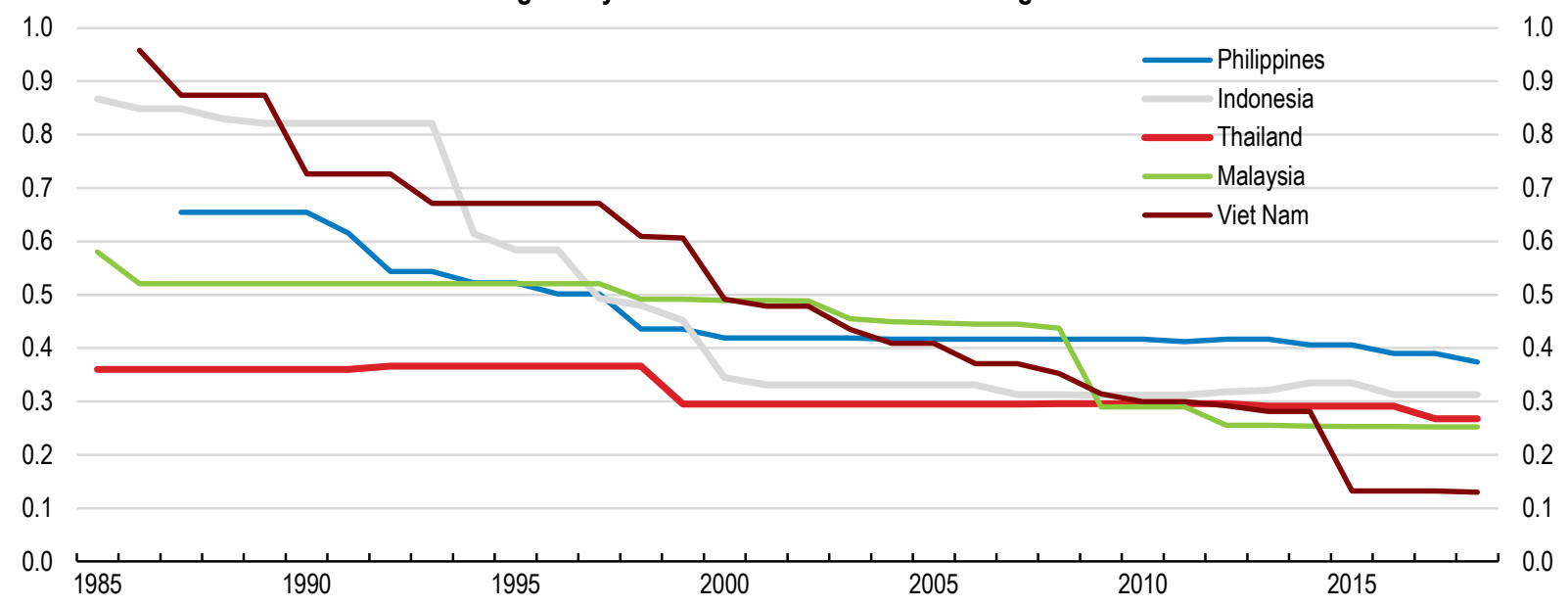

B. FDI regulatory restrictiveness index by sector, 2018

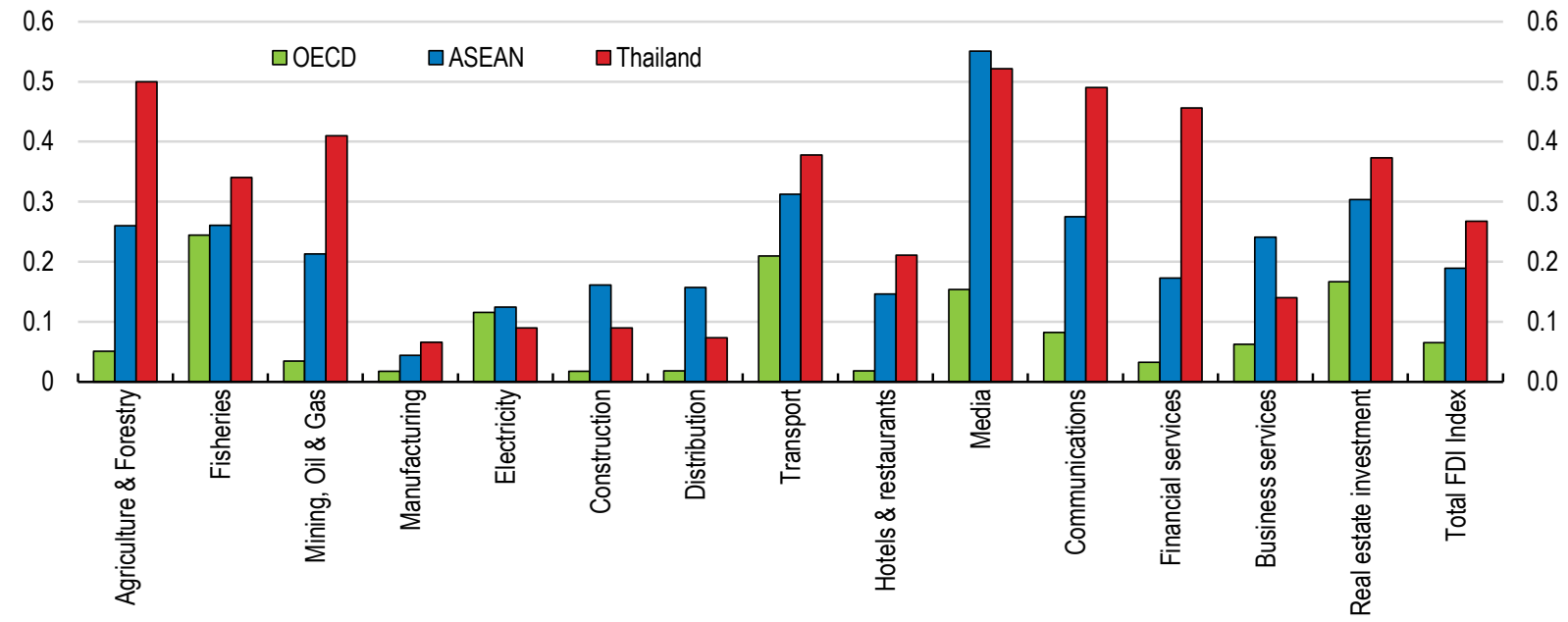

Note: The OECD FDI Regulatory Restrictiveness Index covers only statutory measures discriminating against foreign investors (e.g. foreign equity limits, screening \& approval procedures, restriction on key foreign personnel, and other operational measures). Other important aspects of an investment climate (e.g. the implementation of regulations and state monopolies, preferential treatment for export-oriented investors and special economic zones regimes among other) are not considered. The data reflects regulatory restrictions as of end-December 2018. See Kalinova et al. (2010) for further information on the methodology.

Source: OECD FDI Regulatory Restrictiveness Index Database, http://www.oecd.org/investment/fdindex.htm; see also the ASEAN FDI Regulatory Restrictions Database for information on the underlying measures captured in the Index, https://qdd.oecd.org/subject.aspx?Subject=ASEAN_INDEX.

\section{Developing more service-oriented trade agreements would boost growth}

Because trade in goods and services are more intertwined than ever, trade barriers to both must be addressed in a coherent manner. Particularly, due to the increasing importance of embodied services, manufacturing exports will benefited from services trade liberalisation. Moreover, as trade liberalisation in goods has progressed more than that of services within ASEAN and beyond, advancing the latter becomes more crucial and its gains would be larger. Thailand could therefore reap benefits from the engagement 


\section{4 | ECO/WKP(2020)50}

with more service-oriented Preferential Trade Agreements (PTAs). Particularly, if PTAs contained ambitious liberalisation objectives for services markets, which go beyond the current commitments, this would enhance competition and facilitate reforms in domestic markets. PTAs, such as, the Regional Comprehensive Economic Partnership (RCEP) and the Comprehensive and Progressive Agreement for Trans-Pacific Partnership (CPTTP) that contain progressive regulatory reforms "behind the borders" would boost Thailand's economic growth. For example, under the framework of the Association of South-East Asian Nations (ASEAN), the members are pursuing trade integration, which embraces services trade liberalisation including the facilitation of skilled labour mobility (The ASEAN Secretariat, 2015 [10]]). In its services element, the ASEAN Framework Agreement on Services, Thailand relaxed the restrictions on the number of foreign workers in the banking sector beyond the GATS commitments with regard to workers from the ASEAN countries (ASEAN, 2019[11]).

OECD simulations suggest that Thailand could reap larger gains from PTAs with services trade liberalisation compared with trade liberalisation on goods. The OECD METRO model has been used to estimate the impact of a stylised PTA on Thailand (Box 6). A simulation of four scenarios - tariff reduction on goods, reduction of trade costs related to non-tariff measures on goods, services liberalisation, and simultaneous implementation of the three types of measures - shows that the GDP increase is the largest for services trade liberalisation. This stems both from the relatively large direct share of services sectors in the economy and from the fact that manufactured products have a high content of embodied services. The estimation also suggests that the gains from trade liberalisation including both goods and services would be the largest. As the model does not consider the effects of services trade liberalisation on FDI, productivity growth and the movement of skilled workers, including the long-run dynamic effects, it is likely to be a lower-bound estimate and the actual benefits could be larger. 


\section{Box 6. Impacts of an Asia-Pacific-wide trade agreement}

The OECD METRO model has been used to quantify the impacts on Thailand of a large preferential trade agreement in the Asia-Pacific region. The included countries are Australia, Brunei Darussalam, Cambodia, China, India, Indonesia, Japan, Korea, Malaysia, New Zealand, the Philippines, Singapore, Thailand and Viet Nam. The simulations are designed to allow decomposition of the effects of various trade policy instruments:

- Case 1: Reduction of tariffs - a preferential cut in tariffs on manufacturing goods to $0 \%$ and on food, agricultural goods and natural resources by $50 \%$;

- Case 2: Reduction of trade cost of non-tariff measures (NTMs) on goods - a preferential cut in the ad valorem trade cost equivalents (AVEs) of NTMs on imported goods by $50 \%$ of those differences between a country's AVE of NTM cost and the average cost among all the PTA countries in that sector;

- Case 3: Reduction of NTMs on services - a preferential cut in the AVEs of services trade restrictions in the communication, financial, insurance and business and transport sectors by $50 \%$ and $25 \%$ for high and low restrictive countries respectively;

- Case 4: Simultaneous trade liberalisation - all the three reductions are applied.

Key results are as follows (as dynamic effects are not considered, the results would be a lower bound):

- Among the four scenarios, GDP increases the most in the simultaneous trade liberalisation scenario, as Thailand would benefit from enhanced access on key markets, next to reduced costs of imports from lowering its trade barriers (Table 2). The services trade liberalisation shows the largest contribution. GDP is slightly contained for Case 1, as government expenditure declines because of smaller revenue due to the tariff reduction.

- Production in financial, insurance and business services, which include professional services, decline except under Case 1, as firms substitute away from domestic providers, which have less competitiveness (Figure 14). This suggests the importance of nurturing high-end services. Downstream industries that rely on these services as input benefit from the fall in prices.

- Exports and imports increase most of the sectors in the simultaneous liberalisation scenario (Figure 15). Both the tariff and NTM reduction on goods increase imports of services input used by the manufacturing sectors, while exports of those services decline. This suggests the importance of simultaneous trade liberalisation embracing services.

\section{Table 2. Macroeconomic impacts}

Percentage change from baseline

\begin{tabular}{lcccc}
\hline & Reduction in tariff rates & $\begin{array}{c}\text { Reduction in NTMs on } \\
\text { goods }\end{array}$ & $\begin{array}{c}\text { Reduction NTMs on } \\
\text { services }\end{array}$ & $\begin{array}{c}\text { Simultaneous } \\
\text { liberalisation }\end{array}$ \\
GDP & -0.01 & 0.16 & 0.44 & 0.58 \\
Private consumption & 0.73 & 0.72 & 0.67 & 2.14 \\
Investment & 0.04 & 1.09 & 0.44 & 1.55 \\
Exports & 1.24 & 0.92 & 0.35 & 2.51 \\
Imports & 1.05 & 1.89 & 0.51 & 3.45 \\
Domestic production & 0.24 & 0.42 & 0.17 & 0.82 \\
\hline
\end{tabular}

Source: OECD estimates based on the METRO Model. 
Figure 14. Impacts on domestic production by sector

Percentage change from baseline

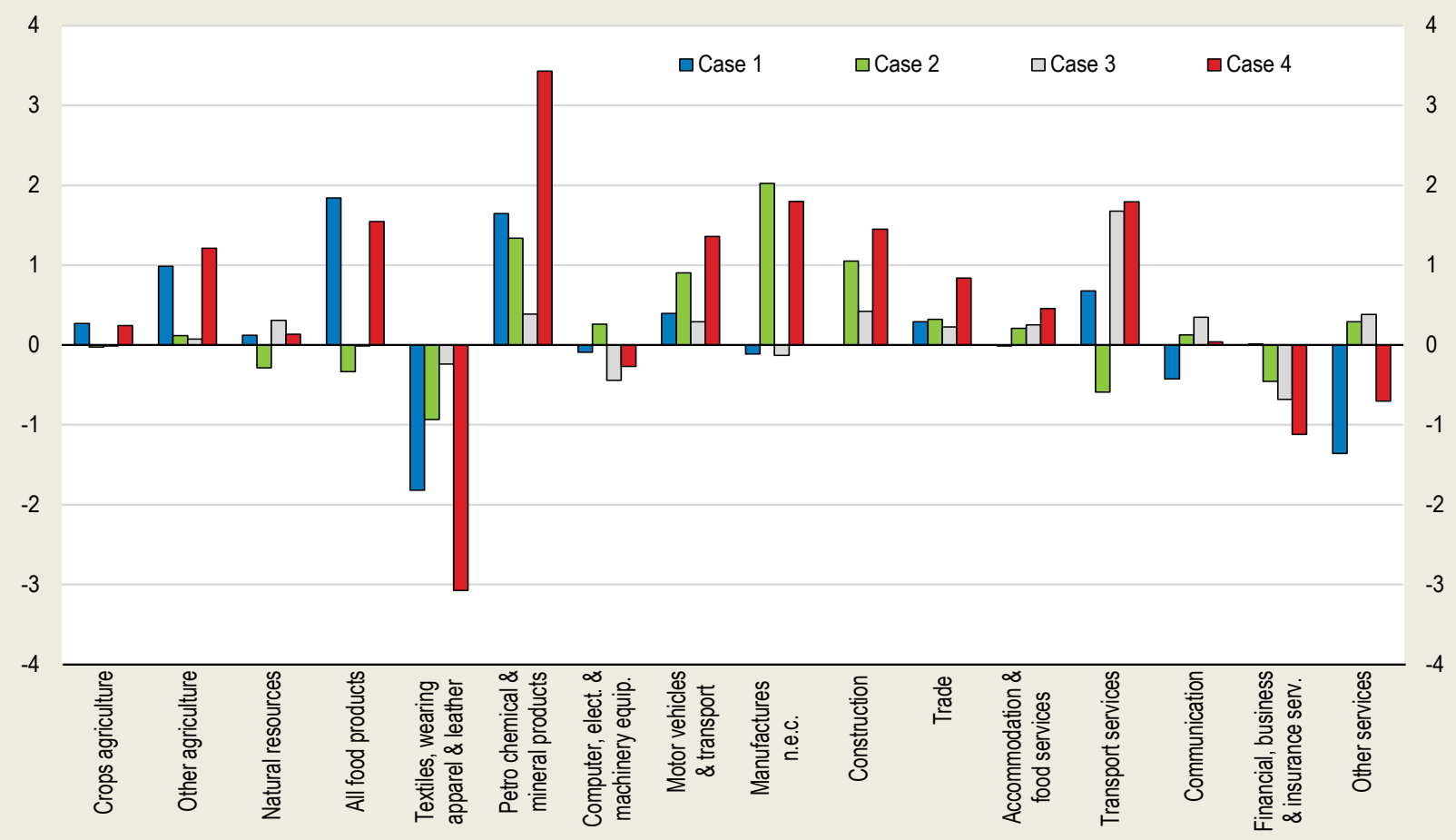

Source: OECD simulations based on the METRO model.

Figure 15. Impacts on exports and imports by sector

Percentage change from baseline case
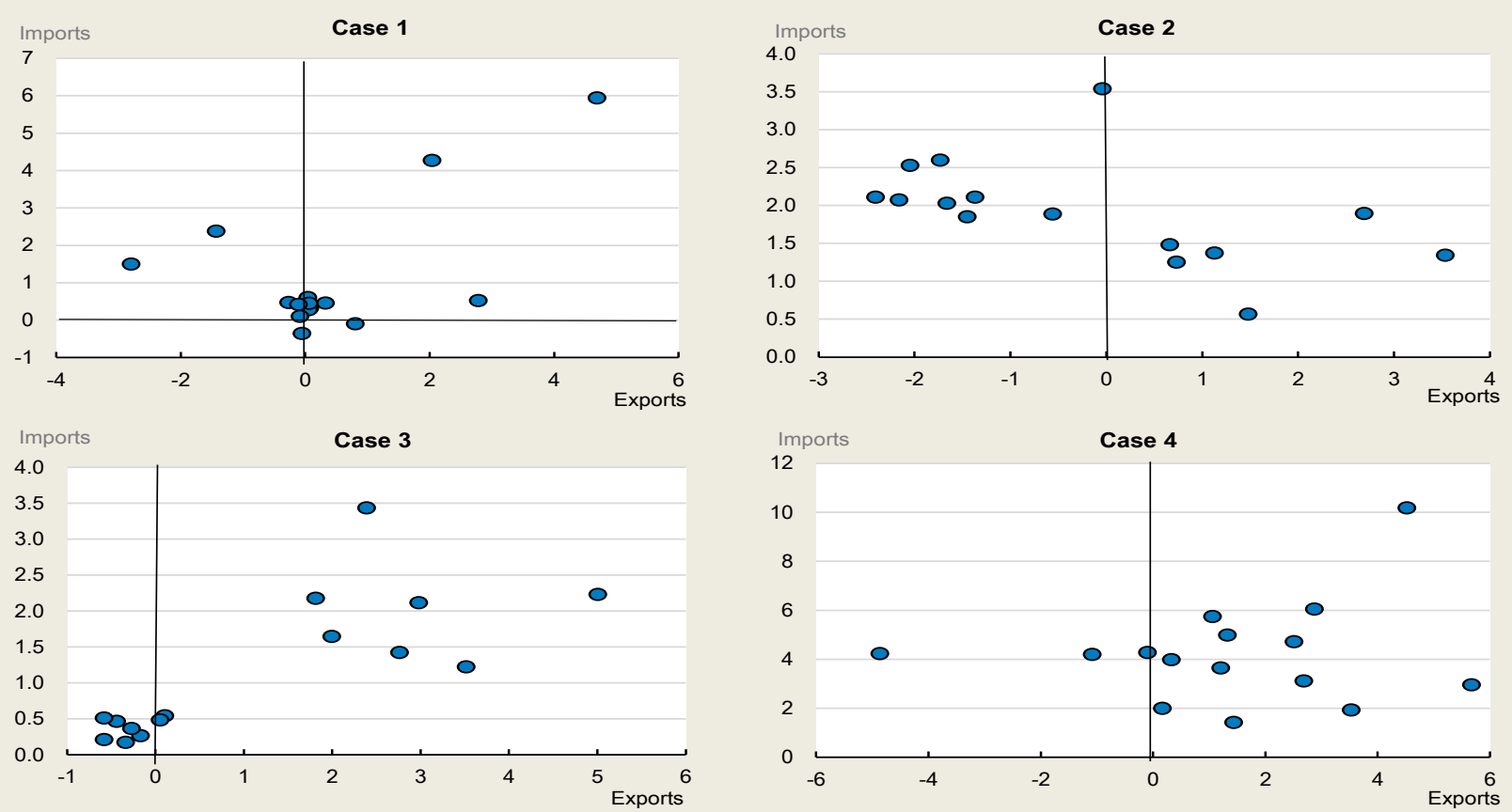

Source: OECD simulations based on the METRO model. 


\section{Trade facilitation is more effective together with services trade liberalisation}

Since the logistics service has become an essential element in international trade, trade facilitation, such as border management, is now an important policy tool to achieve smoother trade in general (OECD, $2018\left[{ }_{[12]}\right]$. As trade facilitation implementation reduces transaction costs for SMEs, it is also helpful for SMEs to connect to international markets. Thailand's scores in the OECD Trade Facilitation Indicators are better than the average of Asia-Pacific, although a gap remains with best practice countries (Figure 16). Since the mid-2010s, the government has taken a couple of measures to reduce the number of documents and improve transparency. Nevertheless, the two weakest performing areas, the transparency and proportionality of fees and inter-agency co-operation have barely improved. As was recommended by the UNCTAD (UNCTAD, 2014[13]), Thailand established a high-level committee to facilitate inter-agency cooperation. Further improvement in functioning, financing and sustainability of the committee would help address remaining shortcomings in both the policy areas (International Trade Centre, 2015[14]).

\section{Figure 16. Thailand's trade facilitation performance has improved}

Score from 0 (worst performance) to 2 (best performance)
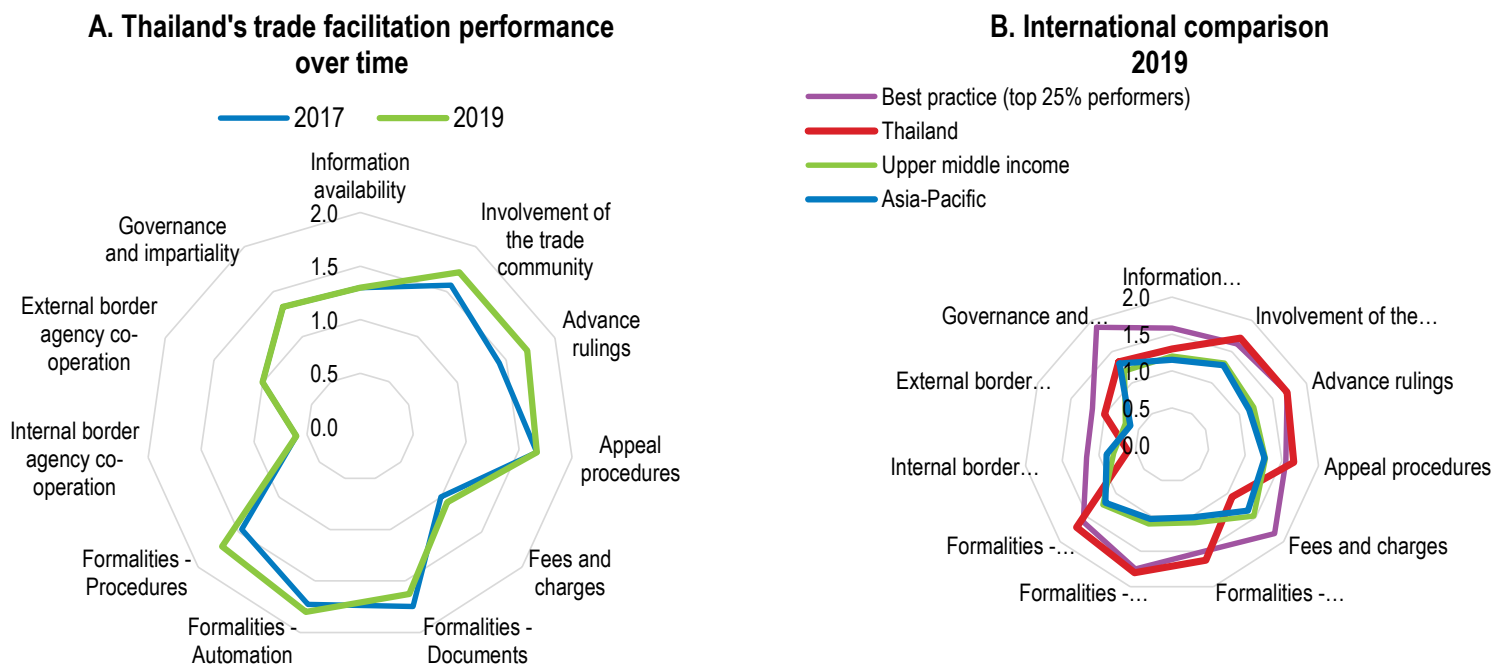

Note: The 2019 series applies the same methodology as 2017, which introduces new measures across all dimensions and particularly in the area of external and internal border agency co-operation, procedures, automation, documents, information availability and involvement of the trade community.

Source: OECD, Trade Facilitation Indicators, http://www.oecd.org/trade/indicators.htm.

\section{Thailand's high-end business services can become more export-oriented}

High value-added services for businesses now play essential roles in the economy: notably, IT and information services, and professional services, the latter of which includes design, consultancy, advertisement, marketing, scientific research and engineering, among others. Nurturing these services to expand into overseas markets would therefore be an important policy agenda for Thailand.

\section{Domestic suppliers need to leverage FDI to be more competitive}

Developing high-end business services is crucial to restore competitiveness of the Thai manufacturing sector, which has weakened recently (see Annex B). Estimates using the OECD TiVA Database reveal 
that these services contents are already embodied in intermediate goods when they are shipped to Thailand (Figure 17). This indicates that the Thai domestic service suppliers cannot deeply integrate in GVCs, because their services are not sufficiently sophisticated to match the needs of export-oriented manufacturers.

Seizing the opportunity borne by FDI is one of the most effective ways to enhance the GVC participation of domestic suppliers in high-end business services. Particularly, domestic suppliers can advance their knowledge and technologies through direct contracts with foreign affiliates. Some emerging countries have succeeded in strengthening this linkage (Figure 18). However, not all suppliers meet standards required by foreign affiliates, and both sides do not know the potential needs and services provision each other. While encouraging foreign affiliates to purchase more from domestic suppliers proves less effective, levelling up domestic suppliers' capacity and addressing information asymmetry between the both sides are useful. Although not confined to the services sector, RROCOMER, Costa Rica's trade promotion agency, helps domestic suppliers develop their skills and capacity including market research, while making co-operation among public institutions more efficient. Likewise, Chile has conducted a Suppliers Development Program since the late 1990s, which provides financial incentives for foreign affiliates to train domestic suppliers.

\section{Innovation in business services could boost their direct exports}

Thailand could expand direct exports of high-end business services, including IT and information services, and professional services. Although the share in overall exports is still small, these direct exports have been expanding rapidly, contrary to the embodied exports of the same services (Figure 19). As Thai enterprises, such as in manufacturing and financial services, are extending their businesses more actively in neighbouring countries, demand for high-end business services provided by Thai suppliers including marketing and maintenance would increase further. Strengthening these Thai services suppliers would also be conducive to their participation in GVCs.

Countries are grappling with policy development that can stimulate service innovation. As these services could also be provided by non-service sectors, the government would need to prepare an economy-wide enabling environment for innovation rather than focusing on specific services sectors. Regulatory reforms would help promote new services (OECD, 2018[15]). In Thailand, regulatory sandboxes have been introduced to facilitate innovation and technology advancement in the services sector, including the one for financial services starting in 2016, which has resulted in the flourishing Fintech sector. Moreover, stimulating business investment in R\&D is still essential. Nevertheless, compared with traditional manufacturing, where in-house R\&D-driven innovation in products is relevant, other types of innovation are deemed more important for these service activities: namely, innovation in process, market and organisation. As the sectors are more data-driven and knowledge-intensive, encouraging investment in ICT and intangible assets would also be essential (Uppenberg and Strauss, 2010 ${ }_{[16]}$ ). Public investment in digital infrastructure would expedite this development. Besides, promoting corporate branding like in Korea, which helps private companies sophisticate their brands including those for exports, would encourage these innovative processes, particularly among SMEs.

Accelerating the digital economy more broadly is also crucial. This is particularly the case for knowledgeintensive services, such as marketing, research and design. Protection of Intellectual Property Rights (IPR), including non-technical innovation, must be a key policy priority. Besides, as recent developments in IT services are more consumer-oriented, protection of personal data is also essential. Thailand is making progress in this area. Under the new Personal Data Protection Act 2019, although its implementation is delayed due to the COVID-19 outbreak, it is not allowed to forward or transfer personal data to a third party unless the data subject has given their written consent. Moreover, the transfer of personal data to foreign countries is possible only if the receiving party has similar personal information protection standards. 
Figure 17. Most of imported high-end services are embodied in intermediate goods

Origin of value added in selected services, embodied in Thai gross manufacturing exports
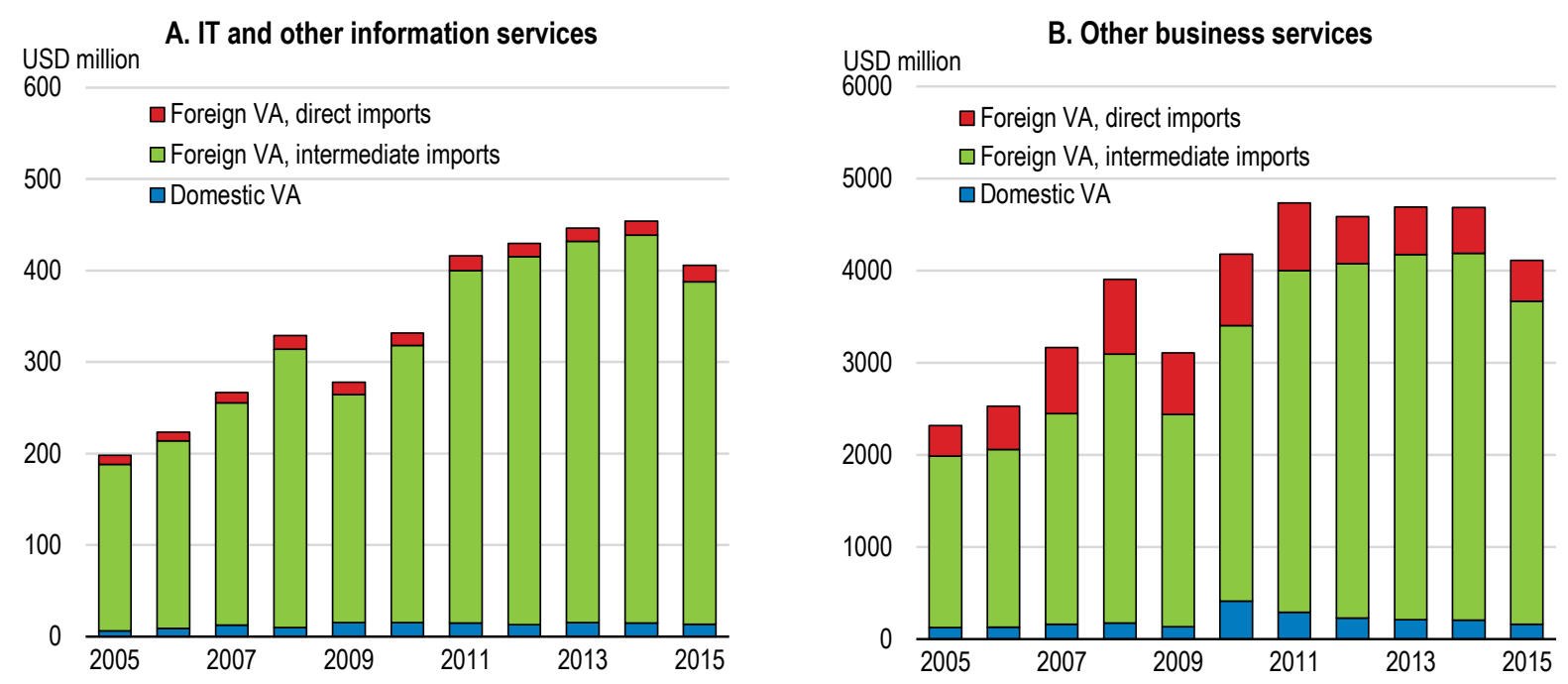

Note: Other business services include professional, scientific and technical services, and administrative and support services. Source: OECD, Trade in Value Added (TiVA) Database.

Figure 18. Thailand's high-end business services participate less in manufacturing GVCs

Share of domestic high-end business services embodied in manufacturing exports

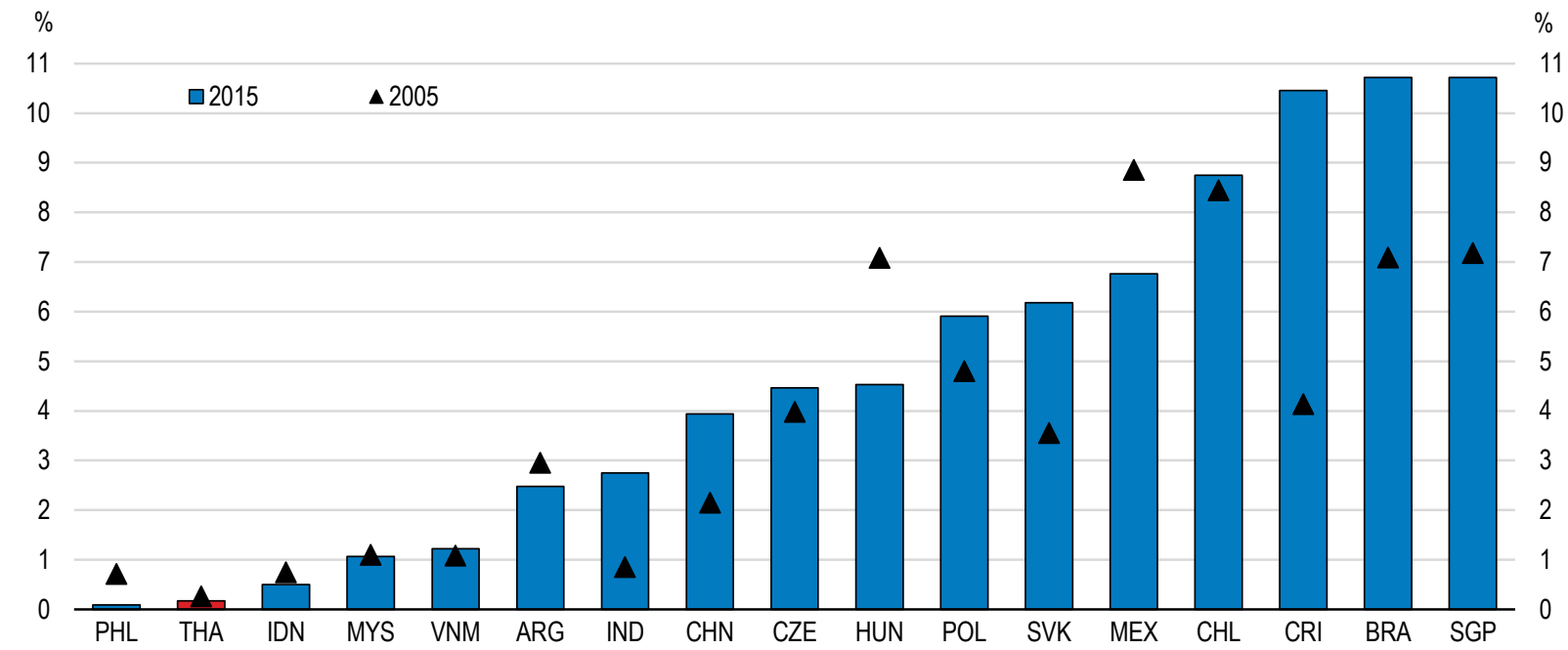

Note: High-end business services are defined as the sum of IT and other information services, and other business services. Exports are measured in domestic value-added terms.

Source: OECD, Trade in Value Added (TiVA) Database. 


\section{Figure 19. Some emerging countries have increased direct exports of high-end services}


Note: High-end business services are defined as the sum of IT and other information services, and other business services. Exports are measured in domestic value-added terms.

Source: OECD, Trade in Value Added (TiVA) Database.

\section{Improved consumer services also benefit the Thai people}

Consumption by foreign customers in a country, such as inbound tourism and education, is essential part of trade in services (Box 2). Particularly, the increasing number of outbound tourists, at more than $4 \%$ growth per year for the last two decades, provided tremendous economic opportunities to competitive countries in tourism, including Thailand, though severely affected by the global COVID-19 pandemic. Since domestic residents are major consumers of these services, improving the quality of the services will have economy-wide impacts and be beneficial to the Thai people as well.

\section{The tourism sector needs to overcome sustainability challenges}

The tourism industry is a major export sector for Thailand. Thanks to its rich nature, unique culture and high hospitality, Thailand is one of the most popular tourist destinations in the world (Figure 20). English is mostly usable in major tourist spots, and medical tourism is one of Thailand's competitive edges. Tourism exports, i.e. consumption by non-resident, account for $11 \%$ of GDP in 2018 , much higher than those of regional peers.

Nevertheless, the Thai tourism industry needs to transform itself into a more productive and high quality services sector to sustain its competitiveness. Even before the global COVID-19 pandemic, the industry was aiming for a higher value-added sector, which provides tourists with unique and vernacular experiences, rather than merely a sector of mass services provision with budget prices and low productivity, such as lodging and meal services. Thailand's second comprehensive National Tourism Development Plan 2017-2021 has sought to support the sustainable growth of tourism by strengthening its brand and safety. As uncertainty is high about the future course of the pandemic and its long-term impacts on people's behaviour, transforming the tourism industry is now more urgent. A number of countries are grappling with the sector's medium- and long-term resilient recovery beyond short-term mitigation and rehabilitation, stressing the importance of sustainable tourism and digitalisation (OECD, 2020[17]), which Thailand is also pursuing (The Tourism Authority of Thailand, 2020[18]). 
As small- and medium-sized enterprises are predominant in the tourism industry, encouraging digitalisation of the sector as a whole could improve its productive capacity through connecting a wider range of consumers and suppliers. Particularly, since the broadband penetration rate is still low in Thailand $(15 \%$ of population in 2020, Office of National Broadcasting and Telecommunications Commission), potential benefits of digitalisation would be large in rural areas. Facilitating digitalisation would also be conducive to broader sustainability development by improving the industry's overall efficiency and helping manage environmental burdens stemming from tourist activities, such as by through time-ticketed entry (OECD, $\left.2020_{[19]}\right)$. For example, a number of districts in the EU countries use digital tools to analyse demand, deliver services to targeted groups, and manage tourist flows (European Commission, 2020[20]). In addition to the infrastructure development, nurturing digital skills among rural areas and SMEs could also be prioritised.

Although endowed with rich natural environment and cultural heritages, Thailand needs to preserve these tourism resources to maintain and even further boost its attractiveness as a tourist destination, while reducing environmental burdens (Figure 21). Since 2018, Thailand has restricted visitors' entry to Maya Bay to restore its coral ecosystem damaged by excessive tourism activities. A number of countries have introduced economic tools or direct measures to conserve tourist sites. The post-COVID-19 recovery would be an important opportunity to take away from mass tourism to this direction, by utilising user fees to manage congestion and environmental pressure, such as dynamic pricing, or limiting the number of visitors in the long run.

The need to enhancing the industry's sustainability capacity also calls for a more comprehensive community-based strategy that involves a wider range of stakeholders and coordinates with other socioeconomic policy measures, as tourism development would entail conflicts of interest within and outside of local communities. For example, air pollution caused by open burning of sugar cane farming is considered as a concern for Si Thep, an ancient town in the central highland, which Thailand nominates on its tentative list to the UNESCO World Heritages. Moreover, protecting heritage sites from natural disasters also requires local communities' involvement as protection measures should be part of the community's overall disaster-risk-reduction strategy. Thailand has a long history of community-based tourism. It aims at facilitating co-operative tourism development in villages, and aims for broader distribution of tourism revenue. Nevertheless, not all households have access to business opportunities, as some activities, such as rafting and homestay, require a large sum of initial investment. Partial co-operation in rural communities and poor financial conditions result in deterioration of tourism resources, which are public goods, in these communities. In some OECD countries, recently, more emphasis is given to management and promotion of local destinations, particularly through the creation of Destination Management Organisations (DMOs) which are formally constituted to deliver local tourism benefits with the involvement of the private sector. Strengthening the function of the community-based tourism, with strong support for local governments would help maintain and restore local tourism resources, while achieving a more equitable distribution of the economic gains. In this regard, the broader environment of local areas should be treated as "common" tourism resources, which is an essential element of high quality destinations. Given that local governments are responsible for water and waste management, these matters would be well integrated with a locally driven tourism development strategy.

Tourism activities in Thailand show strong seasonality, and the length of stay is shorter than in other competing countries: 9.55 days in 2015, while 26 days in Australia and 18 days in the United States. Since tourists tend to spend more and stay longer for cultural and artistic purposes irrespective of season, a number of countries stress the importance of these types of tourism to seek for new market opportunities. For example, New Zealand highlights arts and culture as core priorities for sustainable tourism growth (Creative New Zealand, 2019[21]]). Further strengthening culture- and art-based tourism would also help the industry to diversify its demand and to become a higher value-added sector, creating more skilled jobs. Digitalisation would help equip the tourism industry with more innovative capacity. For example, West of England in the United Kingdom has experimented 5G technology to provide more interactive information on cultural sites to tourists, using some advanced technologies, including Augmented Reality (AR) and 
Virtual Reality (VR). Besides, medical tourism, where Thailand has a competitive edge, could be strengthened further on condition that a high level of universal services to the Thai people is maintained. While a well-managed outbreak containment would furnish its healthcare system with a high reputation, the accelerating digitalisation could also provide new market opportunities abroad.

In Thailand, the bulk of tourists concentrate in a few areas, notably Bangkok and the South. Since ground and port infrastructure is deemed as one of the weaknesses in the Thai tourism sector (Figure 21), improving transportation infrastructure and services would contribute to better connections of potential tourist spots and stimulate the local economy, while reducing environmental burdens caused by overtourism. Moreover, the gateway of international tourist arrival is concentrated in Bangkok. This bottleneck could be addressed by a railway network connecting U-Tapao International airport in the Eastern Economic Corridor and Bangkok.

\section{Figure 20. Thailand is one of the most popular tourist destinations}

International arrivals, millions

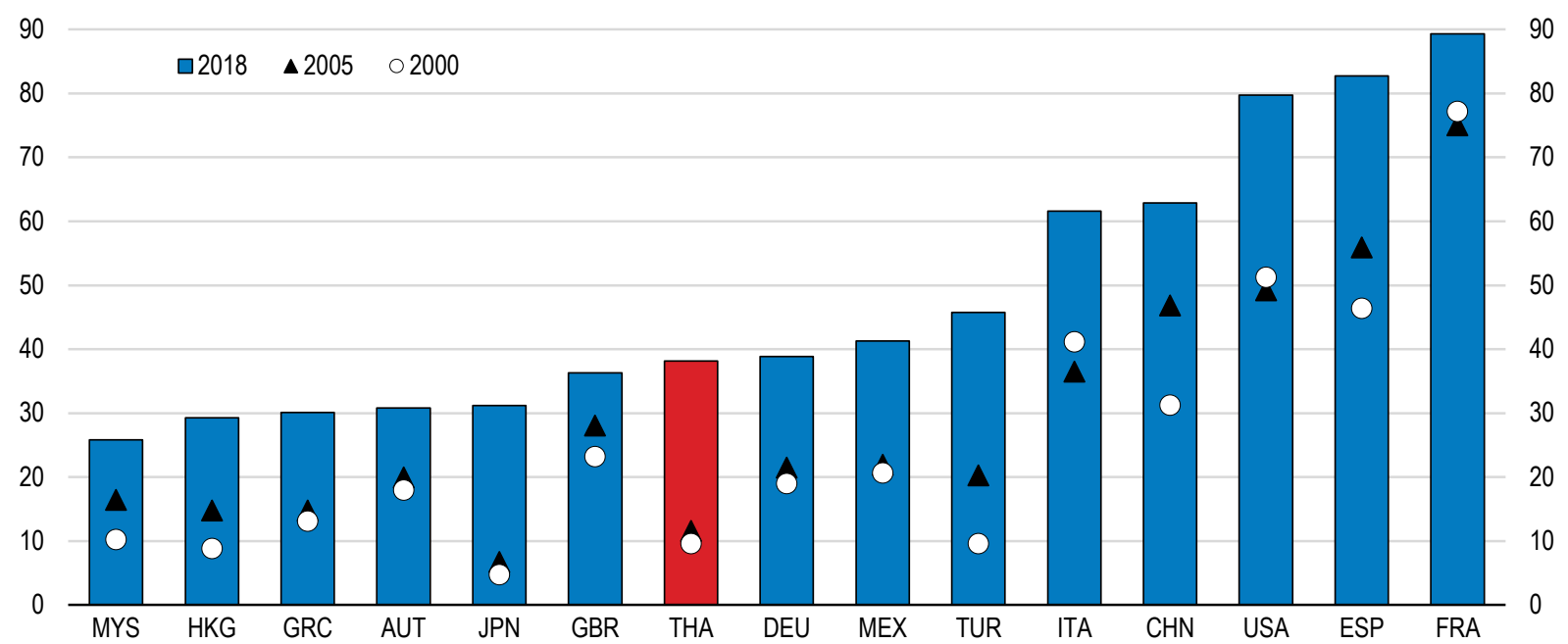

Source: World Bank, World Development Indicators Database. 


\section{Figure 21. Thailand's tourism has an advantage in service infrastructure and natural resources}

Index scale: 1 to 7 (best), 2019

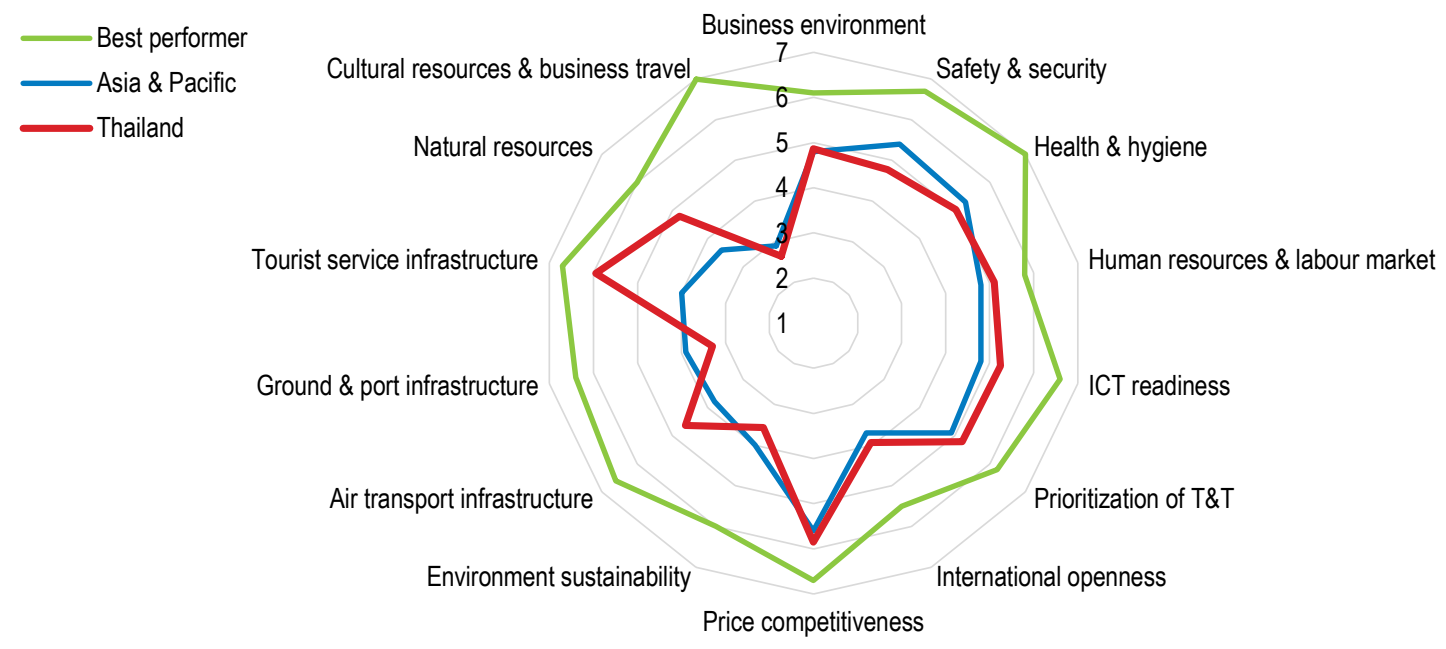

Source: World Economic Forum (2019), The Travel \& Tourism Competitiveness Report 2019 - Travel and Tourism at a Tipping Point.

\section{Global connection can hone higher education's competitive edge}

Expanding international student enrolment in higher educational institutions would benefit the overall economy, by attracting global talents, improving research and education output and nurturing innovative environment through diversification. Moreover, longer-term business and trade links are also expected to occur as a result of hosting international students (Evennett, 2018[22]). In Asia and its surrounding regions, a number of countries seek to become a global hub of higher education. Considering the intensified competition in connecting global talents, making Thailand's higher education more attractive to foreign students would also benefit Thai students. As safety concerns caused by the COVID-19 pandemic would affect students' destination choices, it would be a good opportunity for newcomers, such as Thailand, to consider the internationalisation of the education system.

International rankings of Thai universities are not high and the number of foreign students in higher education is small compared with neighbouring peers (Figure 22), such as Malaysia and Singapore, although tuition fees are less expensive for public universities and programmes are taught in English since the early 2000s. To attract foreign students, a range of policy measures should be appropriately coordinated, including student visas, grants and scholarships, high-quality curriculums and an enabling research environment. Therefore, a number of countries, notably Australia, New Zealand and Malaysia, have developed a comprehensive strategy to strengthen synergies among different policies, while explaining the benefits of accepting foreign students to the public. Aiming for a regional education hub in ASEAN, Thailand supports international student mobility in the region. Nevertheless, a further emphasis could be given to the internationalisation of higher education beyond the ASEAN region. To this end, the government has already sought for collaboration with the EU.

In addition to establishing join or dual degree programmes with foreign universities, supporting foreign universities to open branch campuses within the country is one way to attract foreign students. A number of economies, who host international branch campuses, have succeeded in inviting foreign universities with a high global reputation. This would push up the overall quality of the host economy's education. Dubai has used international branch campuses as a tool to attract skilled foreign workers. Malaysia has encouraged the establishment of international branch campuses in the country since the mid-1990s with the aim of becoming the knowledge-based economy and preventing the persistent brain drains. Other 
Asian countries, such as Viet Nam and Indonesia also moved to this direction recently. In Thailand, under the Foreign Business Act B.E. 2542 (1999), foreign owned or foreign majority entities can set up a branch campus subject to the approval of the Foreign Business Commission. Moreover, since 2017, the government has encouraged reputed overseas universities to set up international branch campuses of the targeted fields in the Eastern Economic Corridor (EEC) area. A wide range of incentives is provided, such as exemptions to foreign ownership of land and the relaxation of visa requirements for overseas staffs. Three foreign universities have already obtained approval. Although it would require full-fledged reforms amid the declining number of students, depending on the outcome evaluation of the current scheme, the government could consider the extension of the scheme beyond the EEC area. Foreign teachers working in the strategic fields outside the EEC area can also apply for the streamlined visa procedure. To facilitate internationalisation of higher education, this could be extended to other disciplines.

\section{Figure 22. Foreign students become more important in higher education in many countries}

Number of students from abroad studying in a given country, percent of total tertiary enrolment in that country

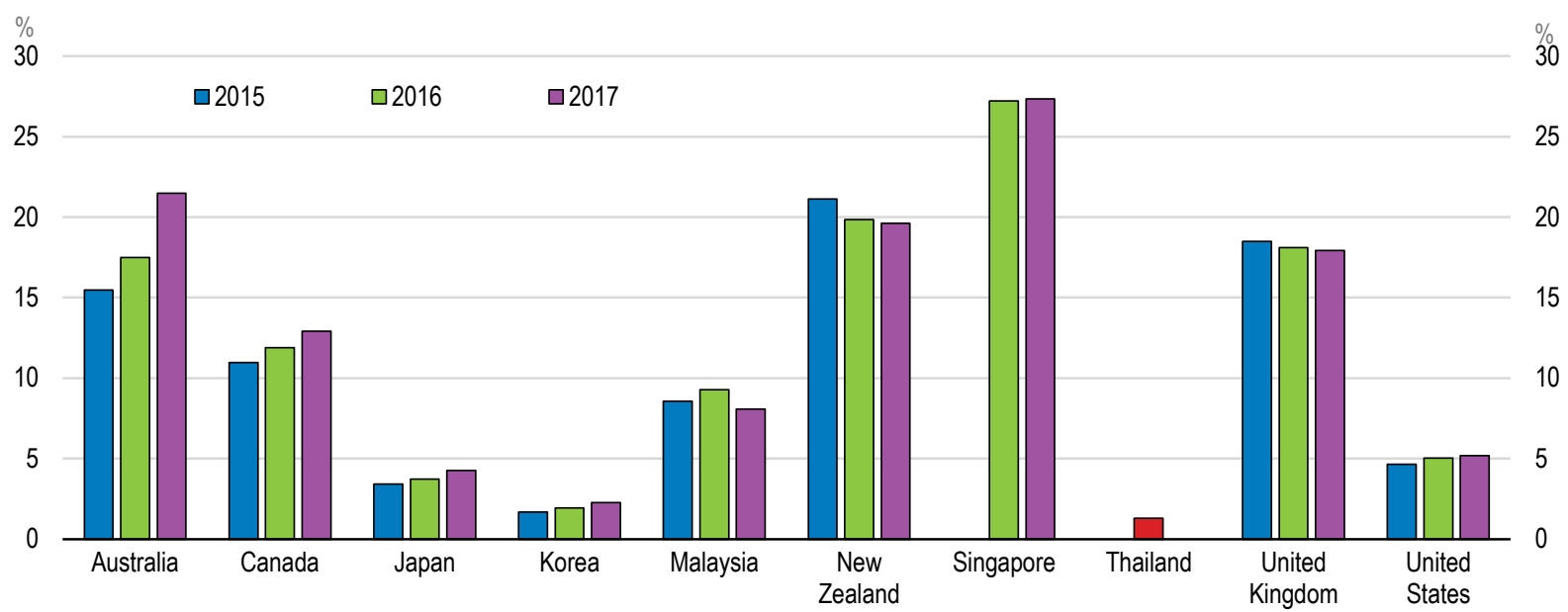

Note: For Thailand, data available for 2016 only. Source: UNESCO, Education Database.

\section{A different skills strategy is needed for trade in services}

Trade integration induces the shift in production activities among sectors in a country, which results in job displacement and wage adjustment. Therefore, governments need to take policy measures that enable workers to move between the sectors without frictions (OECD, 2018 ${ }_{[23]}$ ). Moreover, as GVCs are highly developed in Thailand, employment in supporting business services that contribute to the production of manufacturing products is significant. This requires more policy focus on skills development required in these services sectors, in addition to the mitigation policies against labour adjustment.

To facilitate the transformation to a more service-driven economy, policy measures should support the reand up-skilling of workers and the mobility of workers to skill-intensive service jobs. Empirical work suggests that, although the number of workers with higher education attainment has increased, Thailand faces substantial skills shortages and surpluses, with a significant degree of mismatch. Trade liberalisation would boost demand of business services in Thailand, benefiting highly skilled workers including those who are over-qualified. However, to maximise the benefits of services trade integration, Thailand needs to step up policies to re- and up-skill workers and make the labour market more flexible. This could address the skills shortages and mismatches effectively. Particularly, given the significant regional disparities and 
a large share of agriculture employment in Thailand, facilitating labour force adjustment among different sectors and occupations is crucial.

OECD simulations suggest that participation in PTAs with services trade liberalisation would increase the demand for high skilled workers in the Thai services sectors. The OECD METRO model, which can distinguish five different skills, has been used to estimate the impact of PTAs on sectoral labour demand and on different skills levels (see Annex E). A PTA containing services trade liberalisation increases the demand for mid-skilled jobs, such as clerks, in the business-related services sectors, except for the financial and professional service sectors, which reduce production due to increased imports. Moreover, PTAs that embrace trade liberalisation in goods, both by reducing tariffs and non-tariff barriers, would be likely to increase the demand for high skilled jobs, namely, office management and professionals, and technical and assistant professionals, in a broad range of services sectors (see Annex E). This is because the manufacturing firms that would benefit from a liberalisation of trade in goods require more services input produced by high skilled workers. On the other hand, the demand for lower skilled workers is most likely to decline in services sectors in response to goods trade liberalisation. As the OECD METRO model does not take into account the impact of trade liberalisation on FDI, productivity growth and the movement of skilled workers, including the long-run dynamic effects, the estimates are likely be a lower bound of the actual impact. 


\section{Table 3. Recommendations to enhance Thailand's services trade integration}

\begin{tabular}{|c|c|}
\hline Findings (main findings in bold) & Recommendations (key recommendations in bold) \\
\hline \multicolumn{2}{|c|}{ Removing barriers to services trade integration } \\
\hline $\begin{array}{l}\text { Services sector markets in Thailand are more strictly regulated } \\
\text { than in other Asian countries. }\end{array}$ & $\begin{array}{l}\text { Remove barriers in restricted sectors, particularly regarding the } \\
\text { international mobility of skilled workers by expanding the } \\
\text { coverage of Smart Visa. }\end{array}$ \\
\hline Hiring foreign workers has various impediments. & $\begin{array}{l}\text { Consider further streamlining the extra residence reporting of foreign } \\
\text { workers (TM30). }\end{array}$ \\
\hline Cross-border movement of professional workers is restricted. & Add more professionals to the mutual agreements in ASEAN. \\
\hline Restrictions on FDI tend to be stricter in the services sectors. & $\begin{array}{l}\text { Remove obstacles to FDI by relaxing the rules of capital } \\
\text { thresholds and narrowing listed sectors. }\end{array}$ \\
\hline $\begin{array}{l}\text { Trade integration not only entails job displacement and wage } \\
\text { adjustment, but also increases demand for high skilled workers. }\end{array}$ & $\begin{array}{l}\text { Prepare a two-prong skills strategy: facilitating skills development } \\
\text { required in the skill-intensive services sectors in addition to enhancing } \\
\text { policies to mitigate job displacement. }\end{array}$ \\
\hline \multicolumn{2}{|c|}{ Developing more free trade agreements and implementing trade facilitation } \\
\hline $\begin{array}{l}\text { Thailand has concluded preferential trade agreements (PTAs), } \\
\text { some of which contain services elements. }\end{array}$ & $\begin{array}{l}\text { Pursue PTAs that contain ambitious regulatory reforms beyond } \\
\text { the current commitments under the General Agreement on Trade } \\
\text { in Services (GATS). }\end{array}$ \\
\hline $\begin{array}{l}\text { Concerning trade facilitation, the transparency and proportionality of } \\
\text { fees and inter-agency co-operation have barely improved and lag } \\
\text { behind compared with the Asia-Pacific region. }\end{array}$ & $\begin{array}{l}\text { Use the National Logistics Committee and its sub-committee effectively } \\
\text { to step up trade facilitation. }\end{array}$ \\
\hline \multicolumn{2}{|c|}{ Nurturing high-end services } \\
\hline $\begin{array}{l}\text { Not all domestic service suppliers meet standards required by foreign } \\
\text { affiliates, so that they are not integrated into GVCs. }\end{array}$ & $\begin{array}{l}\text { Help level up domestic suppliers' capacity and facilitate matchmaking } \\
\text { between domestic services suppliers and foreign affiliates. }\end{array}$ \\
\hline $\begin{array}{l}\text { There is no stylised policy frameworks and high-end services can be } \\
\text { provided by non-service sectors. }\end{array}$ & $\begin{array}{l}\text { Set up an economy-wide enabling environment for innovation covering } \\
\text { broader sectors including non-service sectors. }\end{array}$ \\
\hline \multicolumn{2}{|c|}{ Making tourism services more sustainable } \\
\hline $\begin{array}{l}\text { Mass tourism and narrow stakeholder involvement have caused } \\
\text { degradation of tourism resources, while the overall productivity } \\
\text { level of the tourism industry has been low. }\end{array}$ & $\begin{array}{l}\text { Encourage further digitalisation of the tourism industry, especially } \\
\text { in rural areas and the reduction of its environmental footprint. } \\
\text { Involve wider local communities to retain broader environmental } \\
\text { resources, including the management of water and waste. }\end{array}$ \\
\hline The length of tourist stay is shorter than those of other countries & Strengthen culture- and art-based tourism. \\
\hline Tourists concentrate in a few areas. & Improve transportation infrastructure and services. \\
\hline \multicolumn{2}{|c|}{ Internationalising higher education } \\
\hline $\begin{array}{l}\text { The number of foreign students in higher education is smaller than } \\
\text { other countries, while the declining number of Thai students would lead } \\
\text { to supply-demand imbalances in higher education institutions. }\end{array}$ & $\begin{array}{l}\text { Consider developing a strategy to attract foreign students beyond the } \\
\text { ASEAN region. } \\
\text { Expand the disciplines covered by Smart Visa to facilitate international } \\
\text { mobility of foreign teachers in higher education. }\end{array}$ \\
\hline
\end{tabular}




\section{Annex A. Estimation of the services share}

To estimate Thailand's services share in GDP, similar calculations to (Park and Shin, 2012[2]) and (Eichengreen and Gupta, $2009_{[3]}$ ) were conducted for this report.

A quartic relationship between per capita income and the value-added services share is assumed to capture the two waves of services growth. By using the panel data for 155 economies between 1995 and 2018 derived from the World Bank Development Indicators Database, OLS regressions are estimated.

Different from the previous research, the results show negative coefficients for cube items and positive coefficients for quartic items (Table Annex A.1), which suggests that the estimations might capture the growing share of new services sectors, such as digital services, in high-income countries. As it is impossible for the services share to keep increasing, the current situation is considered as a transitional period. (Eichengreen and Gupta, 2009 ${ }_{[3]}$ ) conducted regressions on disaggregated services sectors. Their estimation result also shows that the share of high-end services in GDP, notably computer, legal, technical and advertising, financial intermediation, other business services, and post and telecommunications, increases over the entire range of middle- and high-income levels, and particularly rapidly at high income levels, with no sign of growing more slowly at the high end.

Based on the estimation result of the quartic relationship, Thailand's services share would be $68.5 \%$ if the per capita income of the OECD average in 2018 is applied, which is slightly higher than the calculation based on the linear relationship, $67.8 \%$.

\section{Table Annex A.1. A prolonged second wave of services growth}

Regression of services share in GDP on per capita income

\begin{tabular}{l|c|c}
\hline & \multicolumn{2}{|c}{ Dependent variable is services share in nominal GDP } \\
\hline & $(1)$ & $(2)$ \\
\hline Constant & 491.4380 & -4.159998 \\
\hline & $(3.893348)$ & $(-1.602327)$ \\
\hline Log per capita income & -239.1386 & 6.746076 \\
\hline & $(-3.754191)$ & $(21.89026)$ \\
\hline Log per capita income, squared & 45.16894 & \\
\hline & $(3.809056)$ & \\
\hline Log per capita income, cube & -3.646159 & \\
\hline & $(-3.779235)$ & Yes \\
\hline Log per capita income, quartic & 0.109212 & 3720 \\
\hline & $(3.771794)$ & 0.881298 \\
\hline Country Fixed Effects & Yes & \\
\hline Observations & 3720 & \\
\hline Adjusted R-squared & 0.882020 & \\
\hline
\end{tabular}

Note: Per capita income is in terms of 2010 constant USD.

Source: OECD calculations. 


\section{Annex B. Revealed comparative advantages}

The Revealed Comparative Advantage (RCA) is an indicator to analyse an industry's comparative advantage of a given country in international trade under the assumption that the market is sufficiently competitive. If a country's industry has a comparative advantage, an RCA index is above one.

The traditional RCA in terms of gross exports is calculated as the share of a country's exports of a product in total exports divided by the share of world exports of the same product in total world exports. However, as the gross exports of a product include intermediate input imported from other countries, the RCA in terms of gross exports is not an accurate indicator to assess a country's competitive edge in the context of GVCs.

The OECD Trade in Value Added (TiVA) Database can capture the value added created by each country's industry in the fragmented production processes. By using this database, two alternative RCAs were calculated for this report to evaluate Thai industry's competitiveness in GVCs.

\section{RCA in terms of value added}

As more business services are used as intermediate input of manufacturing, to evaluate the comparative advantage of a given service sector, all exported services either directly or indirectly (i.e. embodied in manufacturing goods) should be taken into account, while deducting imported services (Miroudot and Cadestin, 2017[24]).

The RCA in the value-added terms is calculated as the share of value added originating from a given service sector in a country's exports divided by the share of value-added originating from this service sector of all economies in world exports. Similar to the RCA in the gross export terms, a country's industry has a comparative advantage, when an RCA index is above one.

Estimates of the RCA in terms of value added suggest that Thailand has a comparative advantage in basic business services (wholesale and retail trade, financial, and telecommunications services) and tourismrelated services (real estate activities, and accommodation and food services). However, it does not have a comparative advantage in transportation and storage (including logistics) and high-end business services (IT and information, and other business services including professional services) (Figure Annex B.1).

\section{RCA in terms of GVC income}

On the flip side of a coin, manufacturing products now contain a lot of services input. Therefore, a comparative advantage indicator needs to consider all domestic value added ("GVC income") embodied in a given sector's final products (i.e. final demand in a given country or exports). This includes value added generated by supporting industries within a country, but excludes imported value added.

The RCA is defined as the share of domestic value-added contents of a sector's final products in a given economy's total value added as compared to the average share in all economies (Timmer et al., 2013[25]). For example, as for automobile products, it looks at the share of value added in a given country as compared to the average share contributed by all economies. Similar to the RCA in the gross export terms, a country's industry has a comparative advantage, when an RCA index is above one.

Estimates of the RCAs in terms of GVC income suggest that the Thai manufacturing still maintains its competitive edge, but it is deteriorating except for the food processing industry (Figure Annex B.1). The material industry does not have a comparative advantage. 
Figure Annex B.1. Revealed comparative advantages of the Thai services and manufacturing sectors

\section{A. RCA in value added from services sector}

Wholesale and retail trade; repair of motor vehicles

Transportation and storage

Accommodation and food services

Publishing, audiovisual and broadcasting activities

Telecommunications

IT and other information services

Financial and insurance activities

Real estate activities

Other business sector services

Education

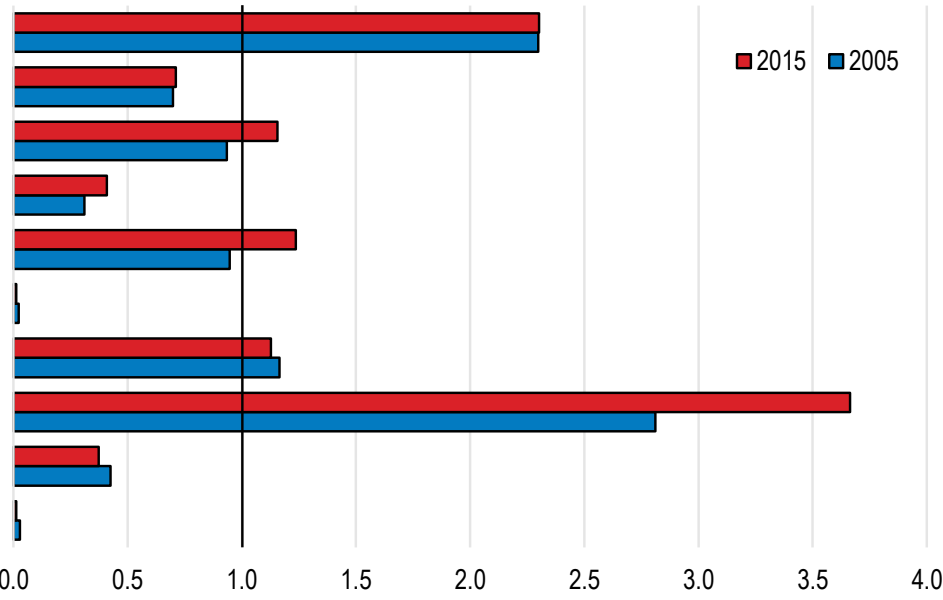

\section{B. RCA in GVC income from manufacturing sector}

Food products, beverages and tobacco

Textiles, wearing apparel, leather and related products

Wood and paper products; printing

Chemicals and non-metallic mineral products

Basic metals and fabricated metal products

Computers, electronic and electrical equipment

Transport equipment
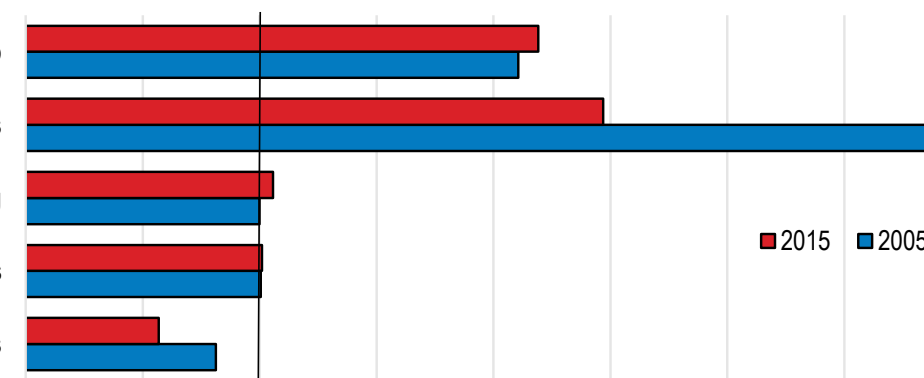

$\square 2015$

$\square 2005$

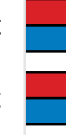

0.0

0.5

1.0

1.5

2.0

2.5

3.0

3.5

Note: An industry has a revealed comparative advantage if its RCA is greater than 1 .

Source: OECD calculations based on OECD, Trade in Value Added (TiVA) Database. 


\section{Annex C. Recovery of exports from the Global Financial Crisis}

To estimate how diversification and trade openness could affect the recovery of a country's exports from shocks, simple calculations were conducted with regard to the export performance of the OECD countries and some emerging economies during the Global Financial Crisis (GFC).

The recovery length (the number of periods from the trough to the time when export volume restored the pre-crisis peak) and the depth (the ratio between the pre-crisis peak export volume and the trough) were measured for each economy. For export diversification, the Export Diversification Index (IMF) and the HH market concentration index (World Bank) were utilised. The former captures a country's export diversity in products and partners and the latter captures the diversity in trade partners only. The both indexes are smaller, if an economy's exports are more diverse. Trade openness is measured as the share of exports and imports in GDP. By using the data for 53 economies, OLS regressions are estimated.

The estimation suggests that the depth is the main determinant of the recovery length (Table Annex C.1). An exponential relationship between them suggests that the deeper the export drop is, the longer a recovery would be. This is because it would be difficult to restore the previous markets as new competitors emerge, reconstruct more damaged supply chains and recover the previous level of production capacity due to the loss of productive labour and capital. Since the sample size is small, the result needs to be interpreted carefully, but an economy that made efforts to expand its trade openness before the crisis would be likely to recover faster. Diversification of trade partners would also be likely to reduce the recovery length.

\section{Table Annex C.1. Export recovery from the GFC - trade openness and export diversification}

Regression of recovery length on depth of export decline, export diversification and trade openness

\begin{tabular}{l|c|c|c|c}
\hline & \multicolumn{4}{|c}{ Dependent variable is log of recovery length } \\
\hline & $(1)$ & $(2)$ & $(3)$ & $(4)$ \\
\hline Constant & 0.961724 & 0.802263 & 0.938110 & 0.965498 \\
\hline & $(4.357741)$ & $(3.597037)$ & $(4.462092)$ & $(4.724609)$ \\
\hline Depth & 0.065242 & 0.075929 & 0.073968 & 0.073957 \\
\hline & $(5.282051)$ & $(6.020628)$ & $(6.143983)$ & $(6.386507)$ \\
\hline Total diversification & & 0.756282 & & \\
\hline & & $(1.524398)$ & & -0.419033 \\
\hline Partner diversification & & & $(1.872373)$ & $(-2.636149)$ \\
\hline & & & & 53 \\
\hline Trade openness & & & 53 & 0.447009 \\
\hline
\end{tabular}

Note: Total diversification is calculated from IMF's Export Diversification Index and partner diversification is calculated from World Bank's HH market concentration index. Trade openness is the share of exports and imports in GDP. The three variables are the difference between the averages of 2000-2003 and 2004-2007. If the variable is negative, exports are more diverse in 2004-2007 than in 2000-2003. For trade openness, if the variable is positive, a country is more open in 2004-2007 than in 2000-2003.

Source: IMF; World Integrated Trade Solution (World Bank); World Bank Development Indicators Database; OECD calculations. 


\section{Annex D. Estimation of productivity in GVCs}

Estimates were conducted for this report to analyse the contribution of value chains on productivity of the Thai manufacturing.

In GVCs, manufacturing involves a range of supporting industries, including services, beyond the national boundaries. Productivity calculation that takes into account production processes in value chains, such as outsourcing, captures a more accurate picture of the economy (Dietzenbacher et al., 2012[26]). Extending this framework, recent empirical work suggests that domestic services input contributes to boosting productivity of manufacturing in many countries (Miroudot and Cadestin, 2017[24]).

Instead of focusing on economic activity of a given industry, economic activities of all the industries in Thailand that contribute to produce final products (i.e. domestic final demand and exports) of a given industry are considered. Services provided by foreign affiliates are also included. For example, an automobile consists of parts, software and services, such as design and testing. An alternative labour productivity ("domestic GVC productivity") is calculated along with these fragmented production processes by using the OECD TiVA Database.

Estimates suggest that domestic GVC productivity of the electrical equipment industry and the automobile industry, which have large supporting industries, grew faster than labour productivity (Figure Annex D.1). Approximately, half of the employment involved in the production of these sectors' final products are in services sectors.

Figure Annex D.1. Domestic GVC productivity by manufacturing sub-sectors

Average annual growth between 2005-2015, per cent

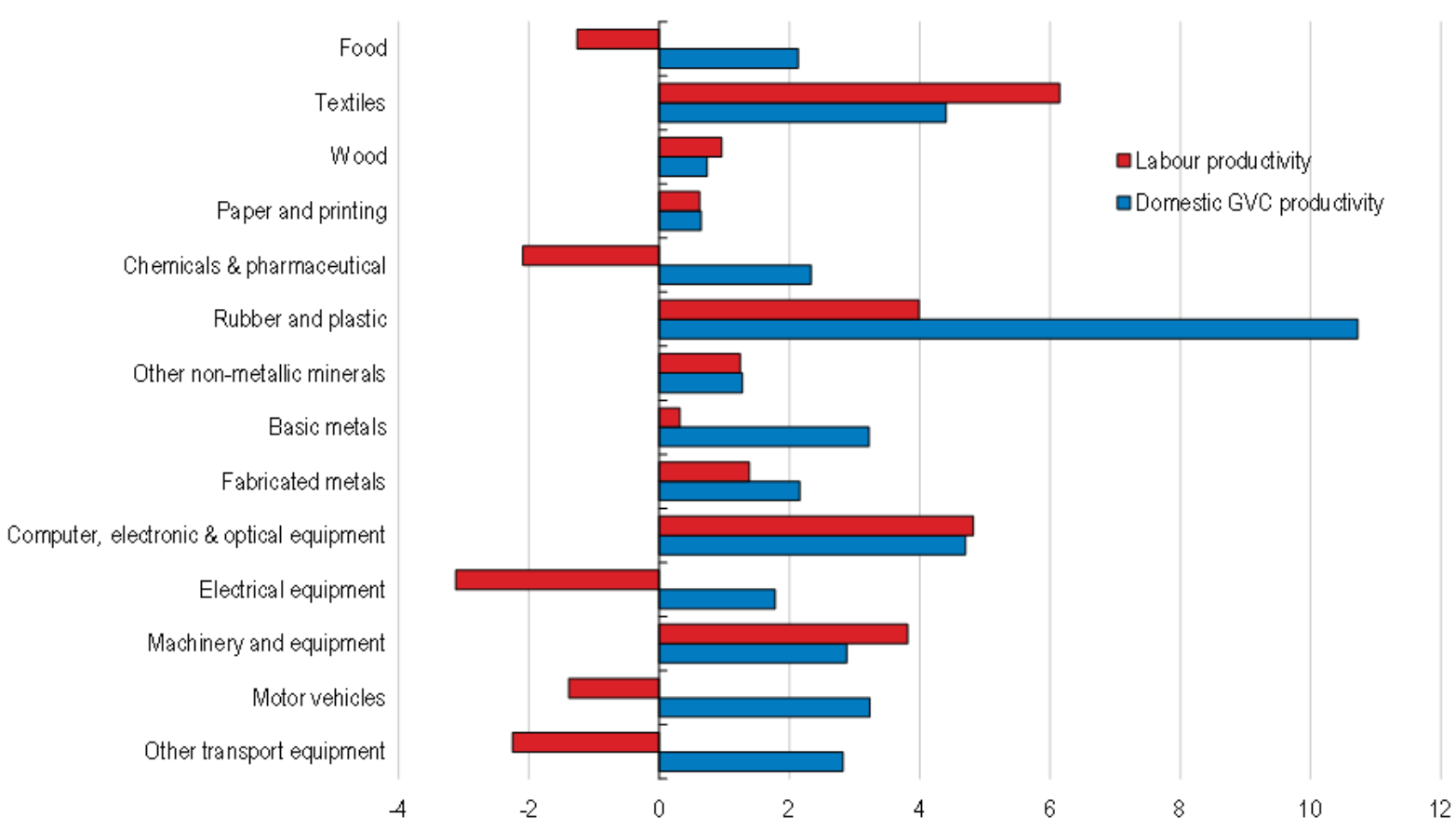

Note: Labour productivity is defined as value added divided by employment.

Source: OECD calculations based on OECD, Trade in Value Added (TiVA) Database; Bank of Thailand; NESDC, National Accounts; and National Statistical Office of Thailand (NSO), Labour Force Survey. 


\section{Annex E. Effects of trade agreements on labour}

To investigate the impacts of preferential trade agreements on the labour market in Thailand, particularly demand shifts among five different skill levels, the OECD METRO model has been used for this report. The results from stylised simulation are as follows (Table Annex E.1):

Table Annex E.1. Impacts of PTAs on different skill levels

Percentage change from the baseline

\begin{tabular}{|c|c|c|c|c|c|c|}
\hline & & $\begin{array}{c}\text { Office } \\
\text { management and } \\
\text { professionals }\end{array}$ & $\begin{array}{c}\text { Technical and } \\
\text { assistant } \\
\text { professionals }\end{array}$ & Clerks & $\begin{array}{l}\text { Service and shop } \\
\text { assistants }\end{array}$ & $\begin{array}{c}\text { Agricultural and } \\
\text { other low skill } \\
\text { workers }\end{array}$ \\
\hline \multirow[t]{4}{*}{ Trade } & Case 1 & 1.2 & 0.6 & 0.3 & 1.3 & -2.4 \\
\hline & Case 2 & 0.2 & 0.4 & 0.1 & 0.3 & 0.6 \\
\hline & Case 3 & -0.1 & 0.2 & 0.0 & -0.1 & 0.0 \\
\hline & Case 4 & 1.3 & 1.2 & 0.5 & 1.5 & -1.9 \\
\hline \multirow{4}{*}{$\begin{array}{l}\text { Accommodation and } \\
\text { food }\end{array}$} & Case 1 & 0.9 & 0.3 & 0.1 & 1.0 & -2.7 \\
\hline & Case 2 & -0.2 & -0.1 & -0.3 & -0.1 & 0.2 \\
\hline & Case 3 & -0.1 & 0.2 & 0.0 & -0.1 & 0.1 \\
\hline & Case 4 & 0.6 & 0.5 & -0.2 & 0.8 & -2.5 \\
\hline \multirow[t]{4}{*}{ Transport } & Case 1 & 1.3 & 0.8 & 1.6 & 2.6 & -1.2 \\
\hline & Case 2 & -1.3 & -1.1 & -1.5 & -1.4 & -1.1 \\
\hline & Case 3 & 1.1 & 1.4 & 1.2 & 1.0 & 1.2 \\
\hline & Case 4 & 1.2 & 1.0 & 1.2 & 2.2 & -1.1 \\
\hline \multirow[t]{4}{*}{ Communication } & Case 1 & 0.5 & 0.0 & 1.2 & 2.2 & -1.6 \\
\hline & Case 2 & -0.1 & 0.1 & -0.4 & -0.2 & 0.1 \\
\hline & Case 3 & -0.1 & 0.2 & 0.0 & -0.2 & 0.0 \\
\hline & Case 4 & 0.4 & 0.2 & 0.8 & 1.8 & -1.5 \\
\hline \multirow{4}{*}{$\begin{array}{l}\text { Financial, insurance } \\
\text { and business }\end{array}$} & Case 1 & 0.7 & 0.2 & -0.1 & 0.9 & -2.8 \\
\hline & Case 2 & -0.6 & -0.5 & -0.7 & -0.6 & -0.2 \\
\hline & Case 3 & -1.1 & -0.8 & -1.0 & -1.1 & -1.0 \\
\hline & Case 4 & -1.0 & -1.1 & -1.8 & -0.8 & -4.1 \\
\hline \multirow[t]{4}{*}{ Other services } & Case 1 & -0.8 & -1.3 & -1.4 & -0.4 & -4.1 \\
\hline & Case 2 & 0.1 & 0.2 & -0.1 & 0.1 & 0.4 \\
\hline & Case 3 & 0.2 & 0.4 & 0.3 & 0.1 & 0.3 \\
\hline & Case 4 & -0.6 & -0.7 & -1.2 & -0.2 & -3.5 \\
\hline
\end{tabular}

Note: Case 1: Reduction of tariffs; Case 2: Reduction of trade cost of non-tariff measures (NTMs) on goods; Case 3: Reduction of NTMs on services; Case 4: Simultaneous trade liberalisation. For the details, see Box 3.6.

Source: Source: OECD estimates based on the METRO model. 


\section{References}

ASEAN (2019), Protocol to Implement the Eighth Package of Commitment on Financial Services under the ASEAN Framework Agreement on Services.

Asian Development Bank (2019), Skilled Labor Mobility and Migration: Challenges and Opportunities for the ASEAN Economic Community.

Asian Development Bank (2012), Asian Development Outlook 2012 Update: Services and Asia's Future Growth, http://www.adb.org (accessed on 4 December 2019).

Creative New Zealand (2019), Draft Aotearoa New Zealand Government Tourism Strategy.

Dietzenbacher, E. et al. (2012), Quantification of the Contributions of Productivity Growth and Globalization to World Consumption Growth Rates (1995-2008), http://www.iariw.org (accessed on 12 January 2020).

Eichengreen, B. and P. Gupta (2009), THE TWO WAVES OF SERVICE SECTOR GROWTH, http://www.nber.org/papers/w14968 (accessed on 4 December 2019).

European Commission (2020), COMPENDIUM OF BEST PRACTICES: 2019 \&amp; 2020 European Capital of Smart Tourism competitions, European Commission.

Evennett, H. (2018), Higher Education Exports - Lords Library briefing - UK Parliament, https://researchbriefings.parliament.uk/ResearchBriefing/Summary/LLN-2018-0079\#fullreport.

International Trade Centre (2015), National Trade Facilitation Committees: Moving towards implementation, http://www.intracen.org.

Miroudot, S. and C. Cadestin (2017), "Services in Global Value Chains: Trade patterns and gains from specialisation", OECD Trade Policy Papers, No. 208, OECD Publishing, Paris, https://dx.doi.org/10.1787/06420077-en.

Noland, M., D. Park and G. Estrada (2012), Developing the Service Sector as Engine of Growth for Asia: An Overview, http://www.adb.org (accessed on 5 December 2019).

OECD (2020), OECD Competition Assessments Report on Logistics - Thailand (forthcoming).

OECD (2020), OECD Economic Surveys: Thailand 2020: Economic Assessment, OECD Publishing, Paris, https://dx.doi.org/10.1787/ad2e50fa-en.

OECD (2020), OECD Investment Policy Reviews: Thailand (forthcoming).

OECD (2020), OECD Services Trade Restrictiveness Index (STRI): Thailand 2019, http://oe.cd/stristri.contact@oecd.org@OECDtrade.

OECD (2020), OECD Tourism Trends and Policies 2020, OECD Publishing, Paris, https://dx.doi.org/10.1787/6b47b985-en.

OECD (2020), The Impact on Competition of State-owned Enterprises in Logistics - A Focus on Small Package Delivery Services - Thailand (forthcoming).

OECD (2020), Tourism Policy Responses to Coronavirus (COVID-19), https://read.oecdilibrary.org/view/?ref=124 124984-7uf8nm95se\&title=Covid-19 Tourism Policy Responses. 
44 | ECO/WKP(2020)50

OECD (2018), Good Regulatory Practices to Support Small and Medium Enterprises in Southeast Asia, OECD Publishing, Paris, https://dx.doi.org/10.1787/9789264305434-en.

OECD (2018), "Market Opening, Growth and Employment", OECD Trade Policy Papers, No. 214, OECD Publishing, Paris, https://dx.doi.org/10.1787/8a34ce38-en.

OECD (2018), Trade Facilitation and the Global Economy, OECD Publishing, Paris, https://dx.doi.org/10.1787/9789264277571-en.

Park, D. and K. Shin (2012), The Service Sector in Asia: Is It an Engine of Growth?, http://www.adb.org (accessed on 5 December 2019).

The ASEAN Secretariat (2015), ASEAN Economic community blueprint 2025, http://www.asean.org (accessed on 13 January 2020).

The Tourism Authority of Thailand (2020), THE BEST: The New Normal of Thai Tourism Tourism Driven under the Supervision of Public Health, https://www.tatnews.org/2020/06/tatunveils-three-part-strategy-for-new-normal-tourism-recovery/.

Timmer, M. et al. (2013), Fragmentation, income and Job an analysis of European competitiveness, http://ssrn.com/abstract id=2354250 (accessed on 12 January 2020).

UNCTAD (2014), National Trade Facilitation Bodies in the World.

Uppenberg, K. and H. Strauss (2010), Innovation and productivity growth in the EU services sector. 